\author{
NiKLaI Patrícia Dominika \\ DOI: 10.15170/DIKE.2020.04.01.09 \\ PhD-hallgató \\ PTE ÁJK
}

\title{
Iskolák a Tanácsköztársaság idején és a baranyai felekezeti tanítók felelősségre vonása
}

\section{Schools during the Hungarian Soviet Republic and the Prosecution of Denominational Teachers in Baranya}

The Hungarian Soviet Republic reorganized schools fundamentally. Efforts were made to reduce the influence of the churches by seeking to achieve religious neutrality on an ideological basis. To do so, schools - not only the institutions maintained by the denominations, but also by the municipality, associations and private persons - were socialized, with the state playing the primary role in education. The Revolutionary Governing Council (government of the Hungarian Soviet Republic) and the Commissariat for Public Education - which replaced the Ministry of Religion and Public Education - took measures to take over schools by the State and displace religion. They strove to reeducate teachers in a communist spirit; priests, nuns, and monks were continued to be employed as teachers only, if they declared themselves secular. In addition to nationalization, they wanted to solve the problems of the education immediately with radical solutions. In several cases, this may have gained the support of teachers, whose vast majority - as presented in various forums - were basically dissatisfied with their previous (financial and social) situation. After the fall of the system, there was a sharp political shift with an even more intense emphasis on religious education. Because of that, the investigation of teachers who supported, or at least served the measures of the Hungarian Soviet Republic proved to be essential. One of the conclusions based on the documents revealed by the disciplinary proceedings is that the denominational teachers, whose task was the religious and moral education of the children, tended to give a firm voice to their political orientation aside from this. However, as several cases show, these prosecutions may have served as a means of personal revenge when most teachers were investigated and, in many cases, false or unfounded charges were reported.

Keywords: Hungarian Soviet Republic, reduction of religion in schools, socialization of schools, investigation of teachers

\section{Kajtár István emlékére}

Amikor Kajtár István professzor úrra gondolok, a könyvek jutnak elsőként eszembe; ez jelentette az egyik közös pontot sajnálatosan rövid, ám annál tartalmasabb ismeretségünk során. Több alkalommal megajándékozott egy-egy könyvvel. Bármilyen kutatási témához fogtam hozzá, azonnal tudott javasolni szakirodalmat, egy egyedülálló megközelítési módot, kiegészítve hasznos tanácsokkal a módszertanra vonatkozóan. Úgy okított folyamatosan, hogy szinte észre sem vettem, 
hiszen mindez könnyed beszélgetésnek tűnt közvetlen, humoros stílusához illően. Bölöny József „Magyarország kormányai 1848-1975” címú rendszerező műve volt az egyik első könyv, amellyel a Professzor úr megajándékozott jó pár évvel ezelőtt; ezt azóta is magamhoz veszem, bármilyen kutatásnak állok neki.

Hasonlóan történt ez alkalommal is, így e tanulmánnyal szeretnék tisztelegni Professzor úr munkássága elôtt oly módon, hogy nem csak a tôle kapott könyvet forgatom buzgón az írás közben, hanem igyekszem szellemiségét is szem előtt tartani, és kellő távolságtartással és objektivitással, ugyanakkor a tettek mögött az embereket meglátva vizsgálódni, amikor a felekezeti tanítók felelősségre vonását értékelem, nem megfeledkezve arról, hogy utólag visszatekintve könnyebb átlátni a következményeket és megítélni egy adott helyzetet, ez azonban az események sodrában cselekvő tanítóktól nem feltétlenül volt elvárható.

\section{A vallás- és közoktatásügy központi szervezeti szabályozása a Tanácsköztársaságban}

A Vallás- és Közoktatásügyi Minisztérium 1848-as létrehozásától több mint száz évig (1951 májusáig) állt fenn ezzel az elnevezéssel, két megszakítással: 1849. augusztus 11. és 1867. február 20. között nem működött, valamint a Tanácsköztársaság idején (1919. március 21. - augusztus 1.) helyét a Közoktatásügyi Népbiztosság vette át. ${ }^{1}$ A Tanácsköztársaság rendszerét közvetlenül megelőzően, a Berinkey Dénes miniszterelnök által vezetett kormányban a vallás- és közoktatásügyi miniszteri pozíció megoszlott, mivel 1919. január 22. és március 21. között ${ }^{2}$ a minisztériumot a vallásügyi s közoktatásügyi igazgatásról szóló 1919. évi V. néptörvény kettéválasztotta. ${ }^{3}$ Önálló vallásügyi és önálló közoktatásügyi minisztérium jött létre: a vallásügyi miniszter Vass János, a közoktatásügyi miniszter Kunfi Zsigmond lett e két hónapra. ${ }^{4}$

Kunfi kinevezésének jelentősége - a történelmi események részletezésétől eltekintve, e helyütt csupán a későbbi Tanácsköztársaság politikai irányultságát számba véve - abban áll, hogy ő ekkor, a polgári demokratikus kormányzat idején a Szociáldemokrata Párt tagja volt, amellyel Károlyi Mibály kénytelen volt megegyezni, ennek eredményeként kapták a szociáldemokraták (három másik tárca mellé) a közoktatásügyi minisztériumot. Kunfi ennek megfelelően az oktatásügy terén elôkészíthette (volna) a szociáldemokrata és kommunista hatalomátvételt és az azzal járó intézkedéseket (mint például az iskolák államosítását), azonban március 21. előtt a minisztérium és az egyetemek személyi kérdéseivel foglalkozott, az elemi iskolák terén nem vezetett be jelentôsebb változásokat. ${ }^{5}$ A polgári demokratikus kormányok Károlyi, majd Berinkey vezetésével ugyan meghirdették az egyházak és az állam elválasztására épülő oktatáspolitikájukat, a rendszer stabilizálása érdekében és a felekezetekkel való kompromisszum jegyében az államosításra nem került sor még Kunfi közoktatásügyi minisztersége alatt sem, ${ }^{6}$ csupán a tanácsrendszer felállításával, egy erősen radikalizálódott idôszakban, amikor népbiztosként múködött tovább. Az irány azonban már látható volt abból, hogy közoktatásügyi miniszterként március 4-án kiadta 1.746. számú rendeletét a vallásoktatással kapcsolatos teendők alól való mentesítésrôl, amelyben a kötelező vallásoktatást ugyan nem szüntette meg, viszont kimondta, hogy ezen felül sem a tanulók, sem a

\footnotetext{
${ }^{1}$ BÖLÖNY, Magyarország kormányai 187., 203-205.

2 BÖLÖNY, Magyarország kormányai 59.

3 1919. évi V. néptörvény a vallásügyi s közoktatásügyi igazgatásról.

${ }^{4}$ BÖLÖNY, Magyarország kormányai 188.

${ }^{5}$ Lásd: RAVASZ - FELKAI - BELLÉR - SIMON, A magyar nevelés története a feudalizmus és a kapitalizmus korában 146-147.; MANN, Magyar oktatáspolitikusok 87-88.

${ }^{6}$ BENCZE - LADÁNYI, A polgári demokratikus forradalom és az egyházak 327-331.
} 
tantestület tagjai nem kötelezhetők vallásgyakorlatban való részvételre, vallási célokat szolgáló helyiségben való megjelenésre. ${ }^{7}$ Kunfi hivatalban maradt március 21-ét követően is, mindössze megnevezése változott közoktatásügyi miniszterről közoktatásügyi népbiztossá. Ekkortól az események felgyorsultak, az oktatásügy radikális változásainak megvalósítása tekintetében nagy szerepet játszott Kunfi. E pozíciót április 3-ig egy személyben töltötte be, majd ekkor csatlakozott hozzá Lukács György, Szabados Sándor és Szamuely Tibor. A négy fős kollektív Közoktatásügyi Népbiztosság nem volt hosszabb életű, mint az a Tanácsköztársaság más intézkedéseiről elmondható: június 24-én a testületet váltotta Pogány József, ismét egyszemélyi népbiztosként. ${ }^{8}$

A Tanácsköztársaság rendszerében a Forradalmi Kormányzótanács töltötte be a kormány szerepét, élén Garbai Sándor mint a Forradalmi Kormányzótanács elnöke állt. Ennek a szervnek a tagjai immár nem miniszterek, hanem népbiztosok voltak. A vallás és közoktatás területének szétválasztását megőrizték, azonban a vallási ügyekre népbiztost nem neveztek ki; ${ }^{9}$ ez megfelelt annak a koncepciónak, amelyet a Tanácsköztársaság igyekezett minél aktívabban kommunikálni rendeleteiben, jelentéseiben, egyéb irományaiban ${ }^{10}$ az elkövetkező hónapok során is: az államnak a vallásba nincs beleszólása, az mindenkinek magánügye. A vallásügyekért felelős miniszter posztja még a rendszer bukását követően 6 napra felállitott Peidl-kormányban is betöltetlen maradt, viszont e rövid ideig múködő kormánnyal kapcsolatban érdekességképpen megjegyzendő, hogy az önálló közoktatásügyi miniszteri állást a korábbi Forradalmi Kormányzótanács elnöke, Garbai töltötte be 1919. augusztus 1. és 6. között a Központi Munkástanács megbízásából. A szociáldemokraták által felállított, átmeneti kormány megkezdte a Tanácsköztársaság leépítését, Garbai ebben vállalt szerepe közoktatásügyminiszterként a kutatás jelenlegi állása szerint nem ismert. Az augusztus 7-én hivatalba lépő első Friedrich-kormányban a két területet már ismét egyesítve találjuk meg a vallás- és közoktatásügyi minisztert, aki augusztus 15 -tôl Huszár Károly volt; ${ }^{11}$ Huszár még a tanév kezdete előtt megkezdte Tanácsköztársaság iskolákra vonatkozó rendelkezéseinek hatályon kívül helyezését, e körben érvénytelenítette a felekezeti iskolák államosítását is, valamint körlevélben értesítette az egyházakat az állammal való viszonyuk tekintetében az 1918. október 31-i állapot visszaállításáról. ${ }^{12}$

\section{A Tanácsköztársaság iskolákra vonatkozó rendelkezései}

A Tanácsköztársaság rendszere 1919. március 21. és augusztus 1. között állt fenn Magyarországon, azonban e rövid idő alatt alapos és gyors átszervezésekbe kezdtek. Ezek súlyának megértéséhez fontos tisztázni, hogy mi volt a kiindulópont ekkor az iskolákat tekintve. A 19. század közepéig az egyházak gondoskodtak a gyermekek elemi oktatásáról, melynek első töréspontja Mária Terézia és II. Jóxsef nevéhez kötődik: állami oktatási rendszer megvalósítását készítették elő, azonban az 1800as évek elejére világossá vált, hogy nem érkezett el az államosítás ideje. Az 1848-as törekvések

\footnotetext{
7 A magyar közoktatásügyi miniszter 1919. évi 1.746. ein. számú rendelete, a vallásoktatással kapcsolatos teendők alól való mentesítésről https://library.hungaricana.hu/hu/view/OGYK_RT_1919/?pg=695\&layout=s (2020. 07. 13.)

8 BÖLÖNY, Magyarország kormányai 60., 202-206.

${ }^{9}$ BÖLÖNY, Magyarország kormányai 59-61.

10 Lásd például: A Közoktatásügyi Népbiztosság rendelete a szabad vallásgyakorlásról és a vallásszabadság kihirdetéséről, közli: KÖTE - RAVASZ, Dokumentumok a magyar nevelés történetéből 523.; A Közoktatásügyi Népbiztosság rendeletei a szabad vallásgyakorlásról és a vallásszabadság kihirdetésének ellenőrzéséről, közli: KÖTE RAVASZ, Dokumentumok a magyar nevelés történetéből 524.

${ }^{11}$ BÖLÖNY, Magyarország kormányai 61-62.

12 BENCZE - LADÁNYI, A Tanácsköztársaság és az egyházak 336.
} 
között is szerepet kapott a népoktatás állami átvétellel történő modernizációja, jelentős eredményeket azonban ekkor sem értek el. Az osztrák-magyar kiegyezést követően, a felekezetekkel való kompromisszum jegyében született meg az 1868. évi XXXVIII. törvénycikk a népiskolai közoktatásról. A népoktatási törvény előírta, hogy a korábbi gyakorlat alapján fennálló felekezeti iskolák továbbra is e jellegükkel müködhetnek, az egyházak továbbra is alapíthatnak és fenntarthatnak elemi iskolákat. Előrelépés az állami iskolák irányába ekkor annyiban történt, hogy 1868-tól kezdődően az állam, a községek, egyesületek és magánszemélyek is élhettek az iskolaalapítás és fenntartás jogával, de ezzel párhuzamosan a felekezeteket sem fosztották meg ettől. Az állam kiegészítő szerepe jelent meg, tehát oktatási intézményeket ott állított fel, ahol ez más iskola hiányában elengedhetetlennek bizonyult.

A közoktatási intézményeket tekintve ez volt az alapvető helyzet a 20. század kezdetén is, azonban a Tanácsköztársaság idején az egyházak háttérbe szorítása abban a vonatkozásban is megjelent, hogy iskoláikat ekkor államosították. Ennek jogi keretét a Magyarországi Szocialista Szövetséges Tanácsköztársaság alkotmánya adta, amelynek 11. \-a előírta, hogy „A dolgozók igazi lelkiirsmeretszabadságát azzal védi a tanácsköztársaság, hogy elválasztja teljesen az egyházat az államtól, az iskolát az. egybáztól. Vallását mindenki szabadon gyakorolhatja”. ${ }^{33}$ Az alkotmányi rendelkezés megvalósítása érdekében a Forradalmi Kormányzótanács - a Tanácsköztársaság legfőbb irányító szerve - első intézkedései között rendelkezett az egyházi iskolák állami tulajdonba vételéről. Ennek gyakorlati teendőiről a megyei tanácsok művelődési osztályai gondoskodtak. A mûvelődési osztályok vezetői posztjára a legtöbb helyen tanítókat neveztek ki, ezzel megalapozva azt, hogy szakértôk irányítsák a munkálatokat, így történt ez például a Dunántúl jelentős részén: Zala, Vas, Győr, Sopron, Fejér, Tolna, Somogy megyékben pedagógust neveztek ki, Baranyában pedig először a körorvost, majd itt is tanítót tettek meg a múvelődési osztály élére. ${ }^{14} \mathrm{~A}$ munkálat a népbiztos(ok) utasításai szerint történt, amelyben a helyi pedagógusok is gyakran részt vettek, ez adott alapot többek között a későbbi felelősségre vonásukra.

A Forradalmi Kormányzótanács XXIV. számú, 1919. március 29-i rendeletében is megjelent az a jogpolitikai szándék, hogy az egyházi iskolákat megszüntetve az állam gondoskodjon a gyermekek oktatásáról; a rendelet 1 『-a kimondta, hogy „A Magyarországi Tanácsköztársaság az oktatás ügyét állami feladatnak tekinti. Ehhez képest a Tanácsközztársaság valamennyi nem állami nevelési és oktatási intézetet kezzelésbe vesz át. Az intézetek céljaira szolgáló minden ingatlan és ingó ennek a kormányzótanácsi rendeletnek az alapján köztulajdonná válik." ${ }^{15}$ A rendelet végrehajtásáról a közoktatásügyi népbiztos, Kunfi gondoskodott 7. számú rendeletével. Ennek értelmében a községi, felekezeti, társulati, nyilvános és magán fenntartású elemi iskolák kezelését - más nevelési-oktatási intézményekkel együtt - a Tanácsköztársaság vette át. A népbiztosi rendelet rendelkezett az átvétel további részleteiről is. Az átvétel lebonyolítását a megyei tanácsokban alakult művelődési osztályok intéző bizottságaihoz delegálta, amelyek munkáját a Népbiztosság által kiküldött számvevők segítették. E bizottságok kötelessége volt az intézményekhez tartozó ingatlanokról jegyzék felvétele, az ingókról szóló leltár, az iskola alkalmazottait valamint tanulóit tartalmazó nyilvántartás

\footnotetext{
13 A Magyarországi Szocialista Szövetséges Tanácsköztársaság alkotmánya.

${ }^{14}$ KOMLÓSI, A Tanácsköztársaság közoktatásügyének néhány kérdése, különös tekintettel a Dunántúli iskolákra. 30.

${ }^{15}$ A Forradalmi Kormányzótanács XXIV. számú rendelete, szövegét közli KÖTE - RAVASZ, Dokumentumok a magyar nevelés történetéből 517.
} 
elkészítése. ${ }^{16} \mathrm{Az}$ államosítás néhol helyi buzgóságból már korábban, az átvételről szóló rendelet kiadása előtt megtörtént, így például a Somogy megyei Balatonbogláron, Rékáspusztán és Niklán. ${ }^{17}$

A tanítók jogállására vonatkozóan a Forradalmi Kormányzótanács és a Népbiztosság rendeletét a továbbiakban egymással összevetve érdemes elemezni. A Forradalmi Kormányzótanács rendelete hangsúlyozta, hogy a cél a munkás réteg múveltségi szintjének emelése, ennek érdekében pedig igyekeznek integrálni „mindazokat, akik a Tanácsköztársaság társadalmába és szellemébe beilles₹zednek”, így a Tanácsköztársaság szolgálatába veszi át a nem állami nevelési és oktatási intézmények alkalmazottait. Ezzel összhangban a Forradalmi Kormányzótanács rendelete, illetve az azt kiegészítő népbiztosi rendelet rögzítette, hogy az egyházi személyek (papok, apácák, szerzetesek) mint tanítók munkájukat csak abban az esetben folytathatják, ha nyilatkozatot tesznek két tanú előtt, hogy „világi személyekeké lesznek”, magukat többé egyházi személynek nem tekintik és a Tanácsköztársaság szolgálatába lépnek. E nyilatkozatot az átvételt foganatosító bizottságon keresztül az átvételt irányító bizottságnak kellett beküldeni. Amennyiben ezt nem tették meg az oktatási intézetek átvételét foganatosító bizottságok megalakulását követő tíz napon belül, nem múködhettek tovább e minőségükben. A Tanácsköztársaság szolgálatába állás a kormányzótanácsi rendelet alapján ideiglenes jelleggel megtörtént külön további intézkedés nélkül (a nyilatkozat benyújtásával válhatott állandó jellegưvé), majd ezt megerősítendő, a közoktatásügyi népbiztos hatáskörébe utalta a tanítók „társadalmi felfogására és ismereteire” kiterjedő vizsgálat meghatározását. Az immár világi személyekként a Tanácsköztársaság által alkalmazott egyházi személyek átminősítésével kapcsolatban érdekességképpen megjegyzendő, hogy az iskolák és a fenntartóik e célt szolgáló vagyonának államosítása mellett a bizottságok kötelesek voltak gondoskodni az ilyen tanítók elhelyezéséről, ruházattal és élelemmel való ellátásáról; amennyiben eddig ezekről részükre a felekezet gondoskodott, előleg és segély foganatosítását helyezték kilátásba, mindaddig pedig az átvételt foganatosító bizottság köteles volt garantálni a megfelelő ellátásukat. ${ }^{18}$

Ezt követően a Közoktatásügyi Népbiztosság 1919 júniusi jelentése beszámolt az államosítás állásáról, amelyben említést tett arról is, hogy bár a határmenti területeken lassabban halad a munka, a mûvelődési megbízottak már például Baranyában is tevékenykednek. ${ }^{19} \mathrm{E}$ mûvelődési megbízott a felelősségre vonásokat dokumentáló, a Magyar Nemzeti Levéltár Baranya Megyei Levéltárban (a továbbiakban: levéltár) fellelhetô iratok szerint Lengyel Lász̧ló Béla volt, aki a Tanácsköztársaság bukását követően sietve távozott, nem sok támpontot hagyva maga után tevékenységéről; 1919. november 17-én a megszállt területen lévő alispán nevében a vármegyei főjegyző a tanfelügyelőség megkeresésére a következőt válaszolta a rejtélyes mûvelődési megbízottról: „....) nevezett müvelódési megbírottal semmi nemü bivatalos érintkęésem nem volt és igy magatartására vonatkozólag felvilágositást sem tudok adni. (...) Nevezett müvelódési megbizott hivatalát eltávozásakor sem nekem, sem a járási fószolgabirónak át nem adta”."

A 19-20. század fordulóján már égetô problémának mutatkozó iskolai zsúfoltságot igyekezett enyhíteni a Tanácsköztársaság; a népbiztosi jelentés is beszámol arról a - egyébként más

\footnotetext{
${ }^{16}$ A Közoktatási Népbiztosság 7. K. N. rendelete, szövegét közli KÖTE - RAVASZ, Dokumentumok a magyar nevelés történetéből 519-522.

${ }^{17}$ KOMLÓSI, A Tanácsköztársaság közoktatásügyének néhány kérdése, különös tekintettel a Dunántúli iskolákra 31.

${ }_{18}$ A Forradalmi Kormányzótanács XXIV. számú rendelete; A Közoktatási Népbiztosság 7. K. N. rendelete, szövegeit közli KÖTE - RAVASZ, Dokumentumok a magyar nevelés történetéből 515., 517., 519-522.

${ }^{19}$ Jelentés a Közoktatásügyi Népbiztosság működéséről, szövegét közli KÖTE - RAVASZ, Dokumentumok a magyar nevelés történetéből 601.

${ }^{20}$ MNL BaML VI. 502. Bvm. és Pécs v. Tanfelügyelőségének iratai, 60/1919.
} 
forrásokból is megerősíthető, már a korábbi évtizedekre is vonatkozó ${ }^{21}$ - tényről, hogy a népiskolák egy-egy osztályában 80-120 gyermek tanul, amely így könnyen belátható módon nem lehet eredményes. A Tanácsköztársaság rendszere ezt oly módon kívánta megoldani, hogy bevezették az osztott oktatást az eddigi osztatlan rendszer helyett, hogy egy osztályban 40-nél több gyermek ne tanuljon $^{22}$, illetve a jelentés szerint több tanítót alkalmaztak ${ }^{23}$, ez utóbbi állítást azonban pontos forrásadat nem támasztja alá. Az iskolák államosításával, jelen esetben egy adott községben fennálló több felekezeti valamint községi iskola egyesítésével és így a tanítók összevonásával egy iskolába, továbbá a megszállt területekről érkező menekült tanítóknak az alkalmazásával ${ }^{24}$ ez azonban könnyen elképzelhető. A jelentés is tervbe vette a nyolcosztályos oktatás megvalósítását, ennek részleteiről úgy rendelkezett, hogy 1919 őszére minden iskolaköteles gyermek kötelezhető legyen a részvételre; a további osztályok elhelyezése érdekében - szintén a túlzsúfoltság elkerülése végett új iskolák építését tervezték. ${ }^{25} \mathrm{Ez}$ azonban terv maradt a Tanácsköztársaság augusztusi bukása okán, így a nyolcosztályos népiskolai oktatás bevezetésére két évtizedet még várni kellett Magyarországon: az iskolai kötelezettségről és a nyolcosztályos népiskoláról szóló 1940. évi XX. törvénycikket Hóman Bálint vallás- és közoktatásügyi miniszter adta ki. ${ }^{26}$

Az iskolák államosításának fontos eleme volt a kötelező vallásoktatás megszüntetése. Ellentétben egy 1960-as kiadású szakirodalmi mú állításával ${ }^{27}$, a Tanácsköztársaság alkotmányának sem 10. \-a, sem másik helye nem rendelkezett kötelező jelleggel a vallásoktatás megszüntetéséről. ${ }^{28}$ A kérdésről helyi szinten döntöttek a megyei tanácsok művelődési osztályai, amelyek a legtöbb esetben a kötelező iskolai vallásoktatás megszüntetéséről határoztak. ${ }^{29}$ Az eljárásuk során hivatkozhattak arra, hogy a Forradalmi Kormányzótanács illetve a Közoktatásügyi Népbiztosság ugyan nem adott ki konkrét rendeletet a vallásoktatás megszüntetésére, ugyanakkor az következik az iskola és az egyházak elválasztásából, az iskolák államosításából. ${ }^{30}$ A fővárosi közoktatásügyi népbiztosság kitiltotta az iskolákból a vallásos tárgyú illetve célú tárgyakat, képeket, szobrokat, mondván „Csak azok képeit lássa festve vagy kifaragva az ifjúság, akik az. emberiséget elóbbre vitték, akiknek agya a proletárságért izzott és szive az elnyomottakért dobogott’31 - királyok képei és vallásos tárgyak nem fértek bele értelmezésük szerint ebbe a körbe. Baranyavármegye Közművelődési Osztálya 1919. július 5-én adta ki rendeletét a községi művelődési osztályok részére, amely alapján a „kereszt és minden vallásra vonatkozó tárgyak az iskolateremböl kellö tapintattal eltávolítandók". 32 Erre a levéltárában

\footnotetext{
${ }^{21}$ Ezeket az adatokat lásd például: NIKLAI, Die Modernisierung des Volksunterrichts in Ungarn - Umsetzung des Gesetzes über den Volksunterricht im Komitat Baranya nach 1868233.

${ }^{22}$ KOMLÓSI, A Tanácsköztársaság közoktatásügyének néhány kérdése, különös tekintettel a Dunántúli iskolákra 51.

${ }^{23}$ Jelentés a Közoktatásügyi Népbiztosság múködésérôl, szövegét közli KÖTE - RAVASZ, Dokumentumok a magyar nevelés történetéből 606.

${ }^{24}$ UjVÁRY, A Magyarországi Tanácsköztársaság kulturális politikája. https://honismeret.hu/honismeret-folyoirat/amagyarorszagi-tanacskoztarsasag-kulturalis-politikaja (2020. 07. 13.)

${ }^{25}$ Jelentés a Közoktatásügyi Népbiztosság működéséről, szövegét közli KÖTE - RAVASZ, Dokumentumok a magyar nevelés történetéből 606.

${ }^{26}$ Bôvebben lásd: NIKLAI, A nyolcosztályos népiskolai oktatás bevezetésének hatása az iskolalátogatással kapcsolatos szülői felügyeleti jogra, passim.

${ }^{27}$ RAVASZ - FELKAI - BELLÉR - SIMON, A magyar nevelés története a feudalizmus és a kapitalizmus korában 152.

28 A Magyarországi Szocialista Szövetséges Tanácsköztársaság alkotmánya.

${ }^{29}$ UjVÁRY, A Magyarországi Tanácsköztársaság kulturális politikája. https://honismeret.hu/honismeret-folyoirat/a-

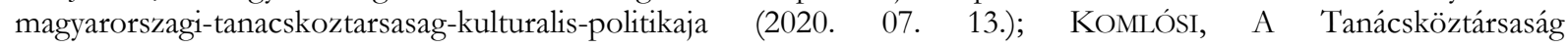
közoktatásügyének néhány kérdése, különös tekintettel a Dunántúli iskolákra 33-34.

${ }^{30}$ SIMON, A Magyar Tanácsköztársaság nevelésügye 13.

31 Az új iskola. Világ, 1919. április 11. 7.

32 BODÓ, Adalékok a tanügyigazgatás és a pedagógusok szakszervezetének Baranya megyei történetéhez a Tanácsköztársaság idejéből 96-98.
} 
rendelkezésre álló dokumentumok alapján helyi szinten intézkedéseket tettek, a későbbi fegyelmi ügyekben ezekre a cselekményekre való hivatkozást is találunk, így például több tanítóval kapcsolatban beszámoltak arról, hogy a tanteremből a keresztet kidobta. Ahogyan az iskolák államosítása is változatos ütemben (illetve néhol egyáltalán nem) valósult meg, úgy a vallásoktatás beszüntetése településenként illetve felekezetenként eltérő volt. Az evangélikus felekezet tekintetében Tolna-Baranya-Somogy egyházmegyében a 72 tanítóból 32 folytatta a vallásoktatást. A római katolikus felekezet általában a hittan további tartására kérte tanítóit, míg az izraelita felekezet a legtöbb esetben ezzel ellentétesen járt el. ${ }^{33}$ A rendszer bukását követô felelôsségre vonások során több felekezeti tanító azzal igazolta tevékenységét, hogy állításuk szerint a vallásoktatást a proletárdiktatúra alatt sem szüntették be. A vallásoktatás azonban már ideiglenes beszüntetését megelőzően, az 1910-es években is érzékeny pontja volt a felekezeteknek, sûrű levélváltások történtek a lelkészek illetve papok, felekezeti tanítók, valamint a tanügyi igazgatás helyi vezetői között. Erre érzékletes példát nyújt az 1912-ben a pécsi evangélikus lelkészi hivataltól a tanfelügyelőnek írt levél, amelyben egyéb mindennapos problémák mellett az államosítás közelségére is felhívta a figyelmet: „V an egy tanítványom, Koch Ferencz. VI. oszt. belvárosi fiuiskolai tanuló, ki a hittanórák. látogatását rendseresen elmulasztja, ellenben sürün adminisztrál a róm. kath. tanulói istentiszteleteknél - amint hallom az ágostontéri templomban. Hogy tudja-e az istentiszteletet végző lelkész, miszerint nevezett fiu evangélikus vallású, én nem tudom, de felteszem róla, hogy nem tudja, mert egyébként nem venné a fiu szolgálatait igénybe. Minden esetre kérem nagybecsü intézkedését, hogy ha már az államositás kü̈zöbén álló iskolai tanulók szolgálatát igénybe veszik is a róm. kath. templomokban, legalább arra legyenek tekintettel a fennálló lelkészelk, hogy ezen célra csupán róm. kath. gyermekeket használjanake fel, - s igy nevezett tanulót ismételt jelentkezés esetén utasitsák el. $\$ 34$

Arról a tényről, hogy a helyi tanítók mennyiben múködtek közre az államosítás ilyen gyors léptékủ megvalósításában, érezhető támogatással számol be az 1979-ben született mú: „E:̨t (...) az is elösegitette, hogy a pedagógusok nagy többsége megértette a feladat nagyságát és jelentöségét, s aktivan támogatta a bivatott szerveket a feladat megoldásában. ${ }^{’ 35}$ Annak indokai, hogy a tanítók jelentős száma támogatta a Tanácsköztársaságnak az egyházak oktatás területrôl való visszaszorítására irányuló intézkedéseit, igen szerteágazóak és az akkori társadalomban mélyen gyökerezőek. E körben fontos megemlíteni az anyagi helyzetüket mint rendezetlen területet, hiszen a tanítók mind egyénileg, mind szervezeti szinten már néhány évtizeddel korábbi időktől kezdve folyamatosan igyekeztek fellépni azért, hogy fizetésüket rendezzék. 1898-ban a Baranyamegyei Tanítótestület éves közgyúlésének meghívója szerint napirendre vették az 1868. évi népoktatási törvény revíziójához javaslataik megfogalmazását; az ehhez csatolt előterjesztés alapján a főbb pontok között szerepelt már ekkor is, hogy „a tanitói fizetés qualifikációja és munkája fontosságának megfelelo legyen és az állampénztárból fižettessék." ${ }^{6}$ A Magyarországi Tanítóegyesületek Országos Szövetsége 1912. január 4-i felhívásában számba vette a korábbi egyetemes gyúléseiket és az azokon elhangzottakat; az 1904-ben tartott alkalommal kapcsolatban megjegyezték, hogy „E\&̧ a gyülést a tanitóság jogos méltatlankodása és

\footnotetext{
${ }^{33}$ KOMLÓsI, A Tanácsköztársaság közoktatásügyének néhány kérdése, különös tekintettel a Dunántúli iskolákra 3336.

34 MNL BaML VI. 502. Bvm. és Pécs v. Tanfelügyelőségének iratai, 175/1912.

35 KÖTE - RAVASZ, Dokumentumok a magyar nevelés történetéből 515.

36 MNL BaML VI. 502. Bvm. és Pécs v. Tanfelügyelőségének iratai, szám nélküli meghívó a „Baranyamegyei Tanítótestület" f. é. deczember hó 7-dikén (szerda), mint az iskolai törvények (1868. évi XXXVIII. t. cz.) kihirdetésének 30. évfordulóján, a megyei székesház közgyúlési termében délelőtt 9 órakor tartandó évi rendes közgyưlésére.
} 
elégületlensége ho:ta létre”, amelynek oka többek között a fizetések rendezésének hiánya volt. ${ }^{37}$ Erre a problémára - elsősorban a felekezeti tanítók esetében, de ugyanúgy elmondható ez az állami, községi tanítók helyzetéről is - az iskolák fenntartói nem reagáltak kellő időben, mivel nem tudtak (vagy esetleg nem akartak) akkora anyagi áldozatot hozni, amellyel kielégítő megoldást lehetett volna találni. A törvényhozás által kiadott rendelkezések ${ }^{38}$ szintén nem bizonyultak elégségesnek. Mindez a Tanácsköztársaság idejére fokozottan jelentkezett és nem volt nehéz meggyőzni a tanítókat arról, hogy támogassák az új rendszert és annak gyors intézkedéseit. A radikális ütemű változások emellett reményt ébreszthettek a tanügy egyéb, évtizedek óta húzódó gondjainak azonnali megoldása iránt, így például a tanítás iránt elhivatott pedagógusok ígéretet kaptak az oktatás - bürokratikus értelemben olykor terhessé váló - felekezeti jellegének megszüntetésére az államosítás által, az iskolák elhanyagolt állapotának javítására, új épületek építésére, az osztott és nyolcosztályos népoktatás bevezetésére, a nemzetiségi nyelven való tanítás elősegítésére, és még sorolhatnánk. Nyilvánvalóan a fentiek mellett még számos indoka lehetett annak, hogy a tanítók azonosulni tudtak (vagy legalábbis alkalmazkodtak) a kommunista elvekkel és a Tanácsköztársaság támogatójaként léptek fel, és nem feltétlenül kellett ehhez mélyen meggyőződéses kommunistaként vagy vallás-, illetve egyházellenesként feltűnniük. Mindazonáltal a rendszer bukását követően alapos vizsgálatok indultak az ilyen személyekkel szemben mind egyházi, mind állami szervek részéről.

\section{A Tanácsköztársaság bukását követő visszarendezés és a felelősségre vonás jogi kerete}

Haller István, aki 1919. november 24. és 1920. március 15. között töltötte be a vallás-és közoktatásügyi miniszteri pozíciót ${ }^{39}$, a Nemzetgyúlésen 1920. április 26-án elhangzott beszédében említést tett arról, hogy a Tanácsköztársaság idején szerepet vállalt pedagógusok ellen indult fegyelmi vizsgálatok még mindig tartanak, illetve még nem is látja úgy, hogy hamarosan a végére érnének. ${ }^{40} \mathrm{E}$ feltevését alátámasztja az, hogy a folyamat a levéltári iratok tanúsága szerint hosszasan folytatódott még az 1920-as, 1930-as, sőt, elvétve az 1940-es évek során is. Az éles politikai váltást - a kommunista-szocialista irányt keresztény, nemzeti konzervatív kormányzat váltotta ${ }^{41}$ - is hozó időszakban elengedhetetlen volt, hogy a proletárdiktatúrában szerepet vállalt személyeket felelősségre vonják. A Horthy-korszak keresztény-nemzeti ideológiájának ${ }^{42}$ részét képezte a valláserkölcsös, hazafias nevelés, amely teljesítését visszamenőlegesen is bizonyítaniuk kellett a tanítóknak, erre szolgált a Tanácsköztársaság fennállása idején tanúsított magatartás kivizsgálása.

\footnotetext{
${ }^{37}$ MNL BaML VI. 502. Bvm. és Pécs v. Tanfelügyelőségének iratai, szám nélküli felhívás a magyar tanítósághoz, Magyarországi Tanítóegyesületek Országos Szövetsége, 1912. január 4.

${ }^{38}$ Lásd: 1893. évi XXVI. törvénycikk a községi, valamint a hitfelekezetek által fentartott elemi iskolákban múködő tanitók és tanitónők fizetésének rendezéséről; 1907. évi XXVI. törvénycikk az állami elemi népiskolai tanitók illetményeinek szabályozásáról és az állami népiskolák helyi felügyeletéről; 1907. évi XXVII. törvénycikk a nem állami elemi népiskolák jogviszonyairól és a községi és hitfelekezeti néptanitók járandóságairól; 1913. évi XV. törvénycikk az állami elemi népiskolai tanitók illetményeinek rendezéséről; 1913. évi XVI. törvénycikk a községi és hitfelekezeti elemi népiskolai tanitók illetményeinek rendezéséről; 1918. évi VIII. néptörvény az elemi népiskolai tanítóknak és tanítónőknek, a kisebb képesítésű gazdasági szaktanítóknak (szaktanítónőknek), továbbá az óvónőknek az állami tisztviselői fizetési osztályokba való sorolása, valamint illetmény- és nyugdíjügyi viszonyainak rendezéséről

${ }^{39}$ BÖLÖNY, Magyarország kormányai 63.

${ }^{40}$ MANN, Oktatáspolitikusok és koncepciók a két világháború között 16.

${ }^{41}$ SCHWEITZER, A magyar királyi köztársaságtól a magyar köztársaságig 63.

${ }^{42}$ A Horthy-korszak egyházpolitikájáról bővebben lásd: HeRGER, Auf dem Weg zur Autokratie? Kirchenpolitik in der Horthy-Ära in Ungarn 69-95.
} 
A Tanácsköztársaságot követően Huszár Károly vallás- és közoktatásügyi miniszter (1919. augusztus 15. - 1919. november 24. $)^{43}$ azonnal intézkedett az iskolák ügyében bekövetkezett változásoknak a visszaállitásáról a nevelési és oktatási intézetek köztulajdonba vétele és a művelődés és oktatás ügyei igazgatásának szabályozása tárgyában a volt tanácskormány által kiadott rendelkezések hatályon kívül helyezéséről szóló 1919. évi 4.507. számú rendeletével. A rendelet 1. \-a hatályon kívül helyezte mind a Forradalmi Kormányzótanácsnak, mind a Közoktatásügyi Népbiztosságnak az oktatási intézetek köztulajdonba vételéről szóló rendelkezéseit. Ennek megfelelően visszaállította a korábbi jogállapotot, mégpedig akként, hogy azokat az iskolákat, amelyekben az állami átvétel ténylegesen megtörtént, a korábbi fenntartók részére haladéktalanul rendelkezésre kellett bocsátani minden ingatlanával és ingóságával együtt, azokban az iskolákban pedig, amelyek átvételét a Tanácsköztársaság alatt nem foganatosították, minden erre irányuló további munkálatot mellőzni kellett. Megszüntette a Forradalmi Kormányzótanács megbízásából múködő oktatásügyi szerveket, érvénytelenítette a tanügyi kinevezéseket, megbízásokat, alkalmazásokat, ezzel együtt visszaállította az azt megelőző szerveket és 1919. augusztus 1-i kezdőnappal visszahelyezte alkalmazásba a korábbi tanítókat és más iskolai alkalmazottakat a Tanácsköztársaságot megelőző állapotok szerint mind a fenntartó, mind a járandóságok tekintetében. A nem állami tanítók - kérésükre - szintén visszahelyezendőek voltak korábbi állásukba (2-3. \-ok). Ez utóbbi rendelkezés vonatkozhatott például azokra az egyházi személyekre, akik nem vállalták azt, hogy a Forradalmi Kormányzótanács és a Közoktatásügyi Népbiztosság rendeletei alapján világi személyekké lesznek, és így nem kerültek át a Tanácsköztársaság alkalmazásába, tehát munkájukat elvesztették. A későbbi felelősségre vonások szempontjából különösen fontos mozzanata a 3. S-nak, hogy a miniszter felhívta az iskolafenntartók figyelmét arra, hogy „a legnagyobb óvatosságot” javasolják a tanítók magatartásának kivizsgálása során, ne szolgálhasson az ellenőrzés arra, hogy ártatlanokat is megvádoljanak. Ezzel együtt hozzátette: „S zü̈kéges azonban, hogy az iskolafenntartók taneröiknek az 1919. március hó 21-ike óta vagy ąt megelózóleg is tanúsitott magatartását a leggondosabb vizsgálat tárgyává tegyék abból a szempontból, nem vettek-e rész̨ a kommunista agitációban, és nem részesek-e a proletárdiktatúra idején elkövetett bolsevista üzelmekben és bünökeben, és nem járultak-e hozzá a nemzet romlásához és általában milyen szerepülk volt az erkölcsi és anyagi romlás bekövetkertében. Amennyiben egyes tanügyi alkalmazottak ilyen tekintetben kifogás alá esnek, a tanitástól való azonnali felfüggesztésük mellett velük szemben az eljárást illetékes fegyelmi hatóságuk útján a legsürgösebben folytassák le, s annak eredményéröl a vallás- és közoktatásügyi miniszterhez azonnal jelentést tegyenek. ${ }^{* 44} \mathrm{E}$ rendelkezés szolgáltatott tehát alapot a kommunizmus alatt közremúködő tanítók felelősségre vonásához.

\section{Baranyai intézkedések a felelősségre vonások iránt}

A Tanácsköztársaság idejéről a levéltár tanfelügyelőségi irataiban nem maradt forrás, azonban következtethetünk a fennálló állapotokra az azt követő, éppen egy évszázada kibontakozó felelősségre vonások irataiból. Baranya megye jelentős része, beleértve Pécs városát is, szerb megszállás alatt állt, így a megyei tanfelügyelőség központja Sásdon múködött, ahol aktívan

\footnotetext{
43 BÖLÖNY, Magyarország kormányai 62.

44 A vallás- és közoktatásügyi miniszter 1919. évi 4.507. számú rendelete a nevelési és oktatási intézetek köztulajdonba vétele és a művelődés és oktatás ügyei igazgatásának szabályozása tárgyában a volt tanácskormány által kiadott rendelkezések hatályon kívül helyezéséről.

https://library.hungaricana.hu/hu/view/OGYK_RT_1919/?pg=1816\&layout=s (2020. 07. 13.)
} 
igyekeztek megvizsgálni azokat, akiknek ténylegesen vagy csak állítólagosan - a fent idézett 4.507. számú vallás- és közoktatásügyi miniszteri rendeletben szereplő óvatosságra való intés ellenére természetesen akadtak ilyen esetek is - bármilyen közük volt a Tanácsköztársaság rendszeréhez. A tanfelügyelőség Pécsrôl Sásdra áthelyezett központjához érkezett a vallás- és közoktatásügyi miniszter 179.539/1919 számú rendelete a tanfelügyelőség vezetójének címezve a tanítók fegyelmi ügyeinek megindításával kapcsolatban. ${ }^{45} \mathrm{E}$ rendelet is megerôsítette, egyúttal felhívta a tanfelügyelőség figyelmét a végrehajtására annak a ténynek, hogy az 1919. március 21-én alkalmazásban állott tanerőknek adott iskola fenntartójával ismét feléled alkalmazásuk, tekintet nélkül arra, hogy a Tanácsköztársaság alatt esetleg az eredetitől eltérő alkalmazásban álltak-e, ennek megfelelően e tanítók jogviszonya az 1868. évi XXXVIII. t.c. (népoktatási törvény) 138. \-a (amely kimondta, hogy „a tanitók élethosszig válasz̨tatnak, és hivatalukból csupán sulyos hanyagság, erkölcsi kihágás, vagy polgári büntény miatt mozdithatók el, a tankerületi iskolatanács itélete folytán. Ily itéletek azonban megerósités végett a közoktatási minister elé terjesztendöke") ${ }^{46}$ és az 1907. évi XXVII. t.c. 2. \$-a (amely a korábbi rendelkezést kiterjesztette a felekezeti tanítókra is) ${ }^{47}$ alapján szüntethető meg. Annak érdekében, hogy megállapíthatóvá váljon, vajon fennállnak-e az állásból való elmozdítás feltételei, szükséges volt kivizsgálni minden (felekezeti és nem felekezeti) tanítónak a Tanácsköztársaság alatt tanúsított magatartását. A miniszter felhívta a tanfelügyelőséget az intézkedések sürgős foganatosítására, így 15 napon belül név szerinti kimutatást várt arról, hogy 1919. március 21. előtt kik és milyen minőségben álltak alkalmazásban a tanfelügyelőség területén lévő állami, illetve nem állami oktatási intézeteknél, valamint közülük kiket és hová osztottak át más iskolához vagy hivatalhoz. Emellett ugyanilyen határidő tartásával köteles volt minden állami, községi, felekezeti, társulati és magán iskola hatóságainak meghallgatásával tájékozódni arról, hogy „kike ąok akik köơönséges büncselekmény vádja alatt állanak és kik azok akik alaposan vádolhatók azzal, hogy magatartásukkal vagy eljárásukekal a tanitói állással össze nem férö módon vétkesen elösegitették a nemzet erkölcsi és anyagi romlását"*8, tehát kik vettek részt a Tanácsköztársaság munkájában. A fegyelmi vétséget állami tanítók esetében az 1907. évi XXVI. t.c. 14. \-ának a) pontjára ${ }^{49}$, nem állami tanítóknál az 1907. évi XXVII. tc. 22. \-ának c) pontjára $^{50}$ alapozták; a nevezett szakaszok a tanítók által elkövethető fegyelmi vétségeket sorolják fel, a hivatkozott pontok pedig ezen belül az államellenes cselekedeteket határozzák meg ebben a körben, a két idézett törvényben tartalmilag azonos módon. A miniszter rendelkezése folytán azokat, akik a felhozott bizonyítékok alapján e fegyelmi vétségek elkövetésével alaposan vádolhatók, eljárás alá kellett vonni és állásából ezidőre felfüggeszteni. A felmerült bizonyítékokat a minisztériumhoz fel kellett terjeszteni, emellett az érintett tanítók felfüggesztése és az eljárás megindítása iránt - a hivatkozott törvények ugyanazon szakaszainak megfelelően - a közigazgatási bizottságnak kellett intézkednie. A miniszter a felekezeti tanítók fegyelmi ügyeiben az eljárás

\footnotetext{
${ }^{45}$ MNL BaML VI. 502. Bvm. és Pécs v. Tanfelügyelőségének iratai, 3/1919.

46 1868. évi XXXVIII. törvénycikk a népiskolai közoktatás tárgyában.

47 1907. évi XXVII. törvénycikk a nem állami elemi népiskolák jogviszonyairól és a községi és hitfelekezeti néptanitók járandóságairól.

${ }^{48}$ MNL BaML VI. 502. Bvm. és Pécs v. Tanfelügyelőségének iratai, 3/1919.

49 1907. évi XXVI. törvénycikk az állami elemi népiskolai tanitók illetményeinek szabályozásáról és az állami népiskolák helyi felügyeletéről: „14. $\int 1$. Az állami elemi népiskolai tanitó fegyelmi vétséget követ el: a) államellenes cselekmény által. Ilyennek tekintendö különösen minden cselekmény, a mely a magyar állam alkotmánya, nemzeti jellege, egysége, különállása, terïleti ép sége, továbbá az állam nyelvének törvényben meghatározott alkalmazása, az állam czimere, jelvényei vagy zászlója ellen irányul."

50 1907. évi XXVII. törvénycikk a nem állami elemi népiskolák jogviszonyairól és a községi és hitfelekezeti néptanitók járandóságairól: „22. \1. A községi elemi népiskolai tanító fegyelmi vétséget követ el: c) ha államellenes irányt követ; államellenes iránynak tekintendö különösen minden cselekedet, a mely az állam alkotmánya, nemzeti jellege, egysége, külön állása vagy területi épsége, továbbá az állam nyelvének törvényben meghatározott alkalmazása és az állam czimere, jelvénye és zászlaja ellen irányul.”
} 
megindítását magának tartotta fenn, arra hivatkozva, hogy „ą elmúlt korszak pusztitásai és a fennálló viszonyok parancsoló kötelességemmé teszik a nemzeti érdekek védelme felett való szigorú örködést”, ezért a felekezeti tanítók névsorát és kifogásolt magatartásukra vonatkozó bizonyítékokat közvetlenül hozzá volt szükséges felküldeni. Ezzel együtt azonban hangsúlyozta, hogy ez nem érinti az egyházi főhatóságoknak „azt a jogát, hogy elmult korszak által veszélyeztetett nemzeti érdekek védelme felett saját hatáskörükben is ôrkeödjenek.". ${ }^{51}$ Mindennek a következménye az lett, hogy mind világi, mind egyházi oldalról megindultak a vizsgálatok a tanítók magatartásának kivizsgálása iránt.

A megszállt területen lévő alispán helyett a vármegyei tb. főjegyző kezdte meg a vizsgálatokat, felkérte a tanfelügyelőt a tanítók kommunista irányzatú viselkedésére vonatkozó adatok összegyüjtésére, ${ }^{52}$ egyúttal megküldte neki a római katolikus egyház fegyelmi vizsgálatot lefolytató képviselője részére is továbbított kérését a „communista tanitók felelösségre vonása” tárgyában. A Fent Ferencz, apátplébánoshoz írt levélből kiderül, hogy a római katolikus egyházmegyei tanfelügyelőség is vizsgálatokat indított a tanítók felelősségre vonására az egyházmegye meg nem szállt területén, amely lebonyolításával az említett apátplébánost mint püspöki provicariust bízták meg, illetve Szekszárdon fegyelmi tanácsot neveztek ki kizárólag ezen ügyeknek a kivizsgálására. Az alispán nevében történt megkeresés tartalmazta a római katolikus tanítók nevét, akiket érintő fegyelmi vizsgálattal kapcsolatban együttmúködést kezdeményeztek az egyházi tanfelügyelősséggel Ahogyan a tanfelügyelőt, úgy az apátplébánost is felkérte a jegyző arra, hogy az általa felsorolt római katolikus elemi népiskolai tanítók ellen a fegyelmi eljárást rendelje el, állásuktól őket függessze fel, valamint az egyház által kitűzendő fegyelmi vizsgálat helyéről és idejéről értesítse a polgári hatóságot képviseletének biztosítása érdekében. A levél részletezte, hogy milyen indokok alapozzák meg a vizsgálatot. ${ }^{53} \mathrm{Az}$ indokolások az apátplébánostól a tanfelügyelőségi kirendeltségnek küldött levélben szinte szóról szóra ugyanígy szerepelnek ugyanezen személyek tekintetében, ${ }^{54}$ ezek alább összefoglalva a következőek:

Albauer János (Gödre): a tanácsrendszer kezdetével nyíltan annak hívéül szegődött, Steécz. Péter gödrei katolikus segédlelkészt az iskolás gyermekek előtt tettleg bántalmazta, majd ellenforradalmárként feljelentette, ennek következtében a segédlelkészt letartóztatták és számos meghurcolásban részesült. Részt vett a tanítók kommunista szakszervezetében, a hegyháti járás ügyeinek kommunista szellemben való elintézésében mint a járási munkástanács tagja. Több feljelentést adott be környékbeli földbirtokosok ellen, ellenforradalmi törekvésekkel vádolva őket, ezek alapján ellenük nyomozás volt folyamatban. A gödrei római katolikus tanítónőt, Muttyánszkły Annát is feljelentette a hegyháti járás tanácsánál mint ellenforradalmárt (A tanítónőt később kommunistaként is felelősségre vonják, tehát meglehetősen kereszttűzbe került.). Gödre lakossága ôt múködéséért meggyûlölte, ôt és családját a községből eltávolította és nem hajlandó visszatérését megengedni. ${ }^{55}$ Albauerrel kapcsolatban a tanfelügyelőségi iratok között megtalálható az iskolaszéki jegyzőkönyv a szeptember 28-i ülésről, amelyen az iskolaszéki elnök felkérte a tagokat, hogy panaszaikat a tanítóval szemben adják elő: „Baumgartner József iskolaszéki tag megemlíti, hogy Albauer a bolsevista eszméket vallotta és hirdette, nagy bive volt a bolsevista uralomnak, de nagyobb kár nélküil. Winter Márton iskolaszéki tag helyteleniti és megrója Albauer azon eljárását, hogy Steécz. Péter gödrei segédlelkészt az.

\footnotetext{
${ }^{51}$ MNL BaML VI. 502. Bvm. és Pécs v. Tanfelügyelőségének iratai, 3/1919.

52 MNL BaML VI. 502. Bvm. és Pécs v. Tanfelügyelőségének iratai, 5/1919.

${ }^{53}$ MNL BaML VI. 502. Bvm. és Pécs v. Tanfelügyelőségének iratai, 6/1919.

${ }^{54}$ MNL BaML VI. 502. Bvm. és Pécs v. Tanfelügyelőségének iratai, 22/1919.

${ }^{55}$ MNL BaML VI. 502. Bvm. és Pécs v. Tanfelügyelőségének iratai, 6/1919.
} 
iskolában a gyermekek elött tettleg inqultálta a proletár diketatúra alatt és a nevezett segédlelkészt mint ellenforradalmárt bejelentette és börtönbe burcoltatta. ${ }^{156}$

Csillag Jenő (Egyházbér): „exponált kommunista volt”, a lakosságot „egyháabéri burzsik””-nak nevezte és agyonlövésel, feljelentéssel fenyegette őket, ha a bolsevik uralom ellen panaszkodni mertek. Mint megbízható kommunistát a megyei művelődési osztály kiküldte a budapesti szocialista átképző tanfolyamára. ${ }^{57}$

Gyurkovics Sándor (Alsómocsolád): „községében a németajkú lakosság éretlen elemei által az ottani róm. kath. plébános ellen megindított hajszában vezérszerepet vitt”, a plébánost és a tanítónőt ellenforradalmi törekvésekkel vádolta, nevezetesen, hogy „ök az egész falut fellázitják, éjjel összeeskïvéseket szítanak és minden pillanatban nyílt kitörésre kerülhet a dolog”. Ez alapján ellenük a belügyi és a közoktatásügyi népbizottságok vizsgálatot rendeltek el, valamint ennek eredményeként az ottani plébános számtalan megaláztatásban és sértésben részesült. ${ }^{58}$

Hamberger Ferencz (Liget): községében a lakosság vallásos érzületét mélyen sértő kommunista elveket hirdetett és „, annyira bolseviknek mutatta magát, hogy a lakosság ốt továbbra tanitóul nem akarja”. 59

Forrai István (Magyarszék): vezető tagja volt a hegyháti járási tanítói szakszervezetnek (egész pontosan annak alelnöke volt ${ }^{60}$, községében „exponált kommunista módra” viselkedett. A vallásos kegyeleti tárgyakat az iskolából még az erre vonatkozó népbiztosi rendelet kiadása előtt eltávolíttatta, a hittan tanítását beszüntette. Szintén részt vett a tanítók szocialista átképző tanfolyamán. ${ }^{61}$

Pokorny Márton (Oroszló): a tanácsrendszer kezdetétől kommunista szellemben kezdte tanítani a gyermekeket, kommunista erkölcsi nézetek alapján. A régi tankönyveket bevonta, kommunista tankönyvekből való tanulásra kényszerítette és így is vizsgáztatta őket. Ennek eredményeképpen „községe lakossága ốt továbbra is tanitóul megtürni nem hajlandó”. ${ }^{2}$

Szekeres József (Kisbesztercze): szintén részt vett a „kommunista üzelmekben”, a község fiatalkorú lakossága előtt előadást tartott, azon a „bosleviki elveket hirdette”, régi hatóságokat, községi és körjegyzőket megbízhatatlan sikkasztóknak nevezte, majd „kijelentette, hogy a község minden ügyét egyedül ö van hivatva elintézni és a lakosság elönyére semmit nem fog tenni”. Az iskolás gyermekeknek a „Dícsértessék”-kel való köszönést megtiltotta. ${ }^{63}$

Neubauer Gyula (Felsőmindszent): kommunista viselkedést tanúsított, mint megbízható bolseviket kiküldték a tanítók szocialista átképző tanfolyamára, rábízták a felsőmindszenti tanítói szakszervezet szabályzatának megszerkesztését. „A községi lakosság a letünt tanácsrendsžer alatt tanúsitott viselkedése miatt szintén a legnagyobb fokú idegenkedéssel és bizalmatlansággal viselkedik és gyermekei nevelését rábizni nem akarja. ${ }^{\circ 4}$

Gocsál József (Szatina): „az iskolateremböl, mely ösidōk óta a községi lakosság imaterméül szolgált és abol a litániákat és a vallásos kegyelet tárgyait (kereszt, szenteltvíztartó) szokták tartani, kidobta az utcára, nem engedte meg, hogy a nép itt litániát tarthasson vasár-és ünnepnapokon, úgyhogy április 15. óta a nép ezen a vallásos

\footnotetext{
${ }^{56}$ MNL BaML VI. 502. Bvm. és Pécs v. Tanfelügyelőségének iratai, 17/1919.

${ }^{57}$ MNL BaML VI. 502. Bvm. és Pécs v. Tanfelügyelőségének iratai, 6/1919.

${ }^{58}$ MNL BaML VI. 502. Bvm. és Pécs v. Tanfelügyelőségének iratai, 6/1919.

${ }^{59}$ MNL BaML VI. 502. Bvm. és Pécs v. Tanfelügyelőségének iratai, 6/1919.

${ }^{60}$ BODÓ, Adalékok a tanügyigazgatás és a pedagógusok szakszervezetének Baranya megyei történetéhez a Tanácsköztársaság idejéből 86.

${ }^{61}$ MNL BaML VI. 502. Bvm. és Pécs v. Tanfelügyelőségének iratai, 6/1919.

${ }^{62}$ MNL BaML VI. 502. Bvm. és Pécs v. Tanfelügyelőségének iratai, 6/1919.

${ }^{63}$ MNL BaML VI. 502. Bvm. és Pécs v. Tanfelügyelőségének iratai, 6/1919.

${ }^{64}$ MNL BaML VI. 502. Bvm. és Pécs v. Tanfelügyelőségének iratai, 6/1919.
} 
sžertartáson rész̨t nem vehetett." A felsőmindszenti plébánost, amikor az érdeklődött nála, hogy a hittan tanítását hol és mikor végezhetné, kilökte az utcára, az iskolás gyerekekkel a legdurvábban bánt, a kislányokat „ronda kancáknak” nevezte. Teljesen vallástalan életet élt, az iskolában általa összehívott szatinai lakosok előtt a kommunista vallástalan és erkölcstelen elveket hirdette. A felsőmindszenti plébánost és két szatinai lakost a sásdi forradalmi törvényszéknél ellenforradalmi váddal feljelentette. A községi lakosságot annyira maga ellen haragította mindezen viselkedésével, hogy kijelentették, ,mindaddig nem engedike gyermekeiket iskolába, míg Gocsál a tanitó”. ${ }^{5}$

Miszlai József (Tarrós), Klier Bertalan (Gyümölcsény): a községi lakosság a keresztnek iskolából való eltávolítása és a vallásoktatás nem teljesítése miatt őket szintén rossz szemmel nézi és eltávolításukat kéri. Klierrôl a felsőmindszenti plébános - a főjegyző megkeresésére - úgy nyilatkozott, hogy nem viselkedett kifogásolható módon, „mindenesetre mindkettójük viselkedése fegyelmi eljárással volna tisztázandó” ${ }^{66}$ Ez utóbbit megerősíti az említett felsőmindszenti plébános november 11-i levele, amely azonban a kereszt eltávolítása kapcsán ellentmondást okoz: „Részemröl Klier Bertalam tanitó ellen nincsen semmi panaszom, sốt elismeréssel kell megemlitenem, hogy a Kommün ideje alatt nem adta fel katholikus vallásos meggyözódését, vallásbeli kötelességeinek. buzgón eleget tett, a keresz̨tet s szent képeket az iskolából nem távolittatta el, a bittant év végéig tanitotta. ${ }^{97}$

A felsorolt vádakat nem kezelhetjük megdönthetetlen tényekként, hiszen a föjegyző maga is leírta, hogy azokról csupán jelentésekből és átiratokból értesült a községi elöljáróságok, iskolaszéki elnökök, kerületi egyházmegyei tanfelügyelők részéről, de szükséges, hogy a tanítóknak a "letünt tanácsrendszer alatt politikai téren tanúsitott magatartását és agitatozius tevékenységét" kivizsgálja. Ezért kérte, hogy az apátplébános a kerületi egyházmegyei tanfelügyelők útján hívja fel az iskolaszékeket, hogy a nevezett tanítók elleni panaszaikat sürgősen terjesszék elő, továbbá szólítsa fel az iskolaszéki elnököket, hogy továbbítsák, ha hozzájuk ilyen feljelentés érkezik és enélkül is számoljanak be minden tanítónak a tanácsrendszer alatti magatartásáról.

Albauer, Csillag, Hamberger és Gyurkovics ekkor őrizetben volt Sásdon „elsösorban a közrend és nyugalom érdekéböl, hogy további į̊gató tevékenységet ki ne fejthessenek.”. ${ }^{8}$ Miszlai és Klier kivételével - az ő esetükben látható, hogy a vádak nem olyan súlyosak, inkább csak tisztázás végett vették őket kivizsgálás alá - a tanítókat állásukból felfüggesztették. ${ }^{69}$

A levelet két nappal később, 1919. október 29-én újabb követte, amely bővítette Csillag bűnlajstromát (a „Dícsértessék”-kel való köszönést eltiltotta és azt mondta a gyerekeknek: „Dicsértessék ezután is, de csak igy: Dicsértessék Kun Béla, a világ megváltója”, egy alkalommal pedig így nyilatkozott: „Ha a kommunizmus megbukik, rögtön agyonlövöm magamat””), valamint a vizsgálat alá vont tanítók körét Csonka Andorral és Huber Jánossal az alábbiak szerint: Csonka Andor (Magyarhertelend): a kommunista elveket hirdette, a keresztet az iskolából kivitte, a „Dícsértessék”-kel való köszönéstől a gyerekeket eltiltotta, szorgalmasan részt vett a kommunista gyűléseken. ${ }^{71}$ Huber János (Barátur): nyíltan kommunistának vallotta magát, a „Dícsértessék”-kel való köszönést eltiltotta,

\footnotetext{
${ }^{65}$ MNL BaML VI. 502. Bvm. és Pécs v. Tanfelügyelőségének iratai, 6/1919.

${ }^{66}$ MNL BaML VI. 502. Bvm. és Pécs v. Tanfelügyelőségének iratai, 6/1919.

${ }^{67}$ MNL BaML VI. 502. Bvm. és Pécs v. Tanfelügyelőségének iratai, 348/1919.

${ }^{68}$ MNL BaML VI. 502. Bvm. és Pécs v. Tanfelügyelőségének iratai, 6/1919.

${ }^{69}$ MNL BaML VI. 502. Bvm. és Pécs v. Tanfelügyelőségének iratai, 22/1919.

${ }^{70}$ MNL BaML VI. 502. Bvm. és Pécs v. Tanfelügyelőségének iratai, szám nélkül (984/1919 püsp prov.) püspöki provicarius levele Bvm tanfelügyelőségi kirendeltségének Sásdra, 1919. október 29.

${ }^{71}$ MNL BaML VI. 502. Bvm. és Pécs v. Tanfelügyelőségének iratai, szám nélkül (984/1919 püsp prov.) püspöki provicarius levele Bvm tanfelügyelőségi kirendeltségének Sásdra, 1919. október 29.
} 
„,šéltében-hosszában hirdette, hogy a vallás magánügy, eqután papot csak az fizet, aki akar”." ${ }^{22}$ A megvádolt Hubert egyébként a tanfelügyelő már október 8-án felkereste azért, hogy a „kommunizmus alatt tartott tanitói gyülésekröl fölvett jegyzókeönyveket kivonatos használatra” sürgősen terjessze fel hozzá. ${ }^{73} \mathrm{Az}$ ötletet a tanfelügyelő a föjegyzőtől kapta, aki figyelmébe ajánlotta „a Sásdon több ǐ́ben tartott, így különösen a Szeghalmi, népbiz̨tosi kiküldött részuételével lefolyt tanitói gyüléseken történtek kinyomozását”.74

1919. november 17-én és 24-én kelt leveleiben a püspöki provicarius a vizsgálatot folytatva közölte a tanfelügyelővel, hogy Albauer, Csillag, Hamberger, Forrai, Pokorny, Sz̨ekeres, Gyurkovics, Neubauer, Gocsál, és Klier ellen a fegyelmi tanács javaslata alapján a fegyelmi vizsgálat megtartását elrendelte, emellett Pokorny, Szekeres, Neubauer, Klier ellen a felfüggesztést megszüntette, többiek esetében a felfüggesztés fenntartása mellett állandó járandóságukat kétharmadában hagyta meg. Miszlaival szemben a további fegyelmi eljárást megszüntette. ${ }^{75}$ Csillagot, Hambergert, Gyurkovicsot, Gocsált, Albauert és Szekerest rövidesen átadták az ügyészségnek további vizsgálatokra. ${ }^{76}$ Forrai iratanyagát a főjegyző szintén áttette a kaposvári állami ügyészséghez, amely 1920. január 22-én arról értesítette a tanítót (illetve természetesen másolatban a tanfelügyelóséget), hogy az ellene a „Tanácsköztársasággal összefüggö büncselekmény gyanuja miatt folyamatba tett” nyomozást megszünteti. ${ }^{77} \mathrm{Ez}$ persze nem érintette a párhuzamosan zajló egyházi felelősségre vonást.

A tanítók elleni fegyelmi eljárás hosszasan folytatódott még az 1920-as év során is. A vallásés közoktatásügyi minisztérium 1920. január 12-ei, tájékoztatás iránti sürgetésére válaszolva a tanfelügyelő megküldte a fegyelmi vizsgálat alatt álló tanítókra vonatkozó kimutatását. Eszerint Gyurkovics, Albauer, Csillag, Forrai és Hamberger vizsgálata ekkor még folyamatban volt, előbbi három a kaposvári ügyészségi fogházban, utóbbiak szabadlábon várták az eljárás végét. Időközben a nyomozást elrendelték Csonka és Huber római katolikus felekezeti tanítókkal, valamint Müller Menyhért református, Albert István községi és Hering József római katolikus tanítókkal szemben. ${ }^{78} 1920$ májusában a püspöki provicarius fegyelmi vizsgálatot rendelt el Halmai János jágónaki és Muttnyánszky Anna gödrei római katolikus felekezeti tanítókkal szemben is. ${ }^{79}$ Utóbbi esetében az eljárás egy 1919 novemberében az apátplébánoshoz mint püspöki provicariushoz továbbított ismeretlen feljelentés alapján kezdődött. ${ }^{80}$

Müller ügye felkeltette a vallás- és közoktatásügyi miniszter figyelmét is, aki 1920. február 7én enyhe intés kíséretében kereste fel a tanfelügyelőt, Sándor Lajost. Haller miniszter közölte, hogy tudomására jutott, miszerint a tanfelügyelő a bonyhádi református lelkésznek mint a hidasi református iskolaszék elnökének azt írta, hogy Müller szabadlábra helyezése érdekében - „tekintettel a bitközség álláspontjára és a vizsgálati iratok betekintése után”- előterjesztéssel fog élni, majd ha ez nem járna sikerrel, akkor fog csak helyettes tanító kirendeléséről gondoskodni. Müller polgárember fia

\footnotetext{
${ }^{72}$ MNL BaML VI. 502. Bvm. és Pécs v. Tanfelügyelőségének iratai, szám nélkül (984/1919 püsp prov.) püspöki provicarius levele Bvm. tanfelügyelőségi kirendeltségének Sásdra, 1919. október 29.

${ }_{73}$ MNL BaML VI. 502. Bvm. és Pécs v. Tanfelügyelőségének iratai, 5/1919.

${ }^{74}$ MNL BaML VI. 502. Bvm. és Pécs v. Tanfelügyelőségének iratai, szám nélkül (ad. 511/1919 alisp.) Baranyavármegye alispánjának levele a tanfelügyelőnek, 1919. szeptember. 27.

${ }^{75}$ MNL BaML VI. 502. Bvm. és Pécs v. Tanfelügyelőségének iratai, szám nélkül (984/1919 püsp.prov.) püspöki provicarius levele Bvm tanfelügyelőségi kirendeltségének Sásdra, 1919. október 29.; szám nélkül (ad 1135-1140, 1153, 1154/1919 püsp.prov.) püspöki provicarius levele Bvm tanfelügyelőségi kirendeltségének Sásdra, 1919. november 17.; $110 / 1919$.

${ }^{76}$ MNL BaML VI. 502. Bvm. és Pécs v. Tanfelügyelőségének iratai, 63/1919, 56/1919, 91/1919, 57/1919, 74/1919, 134/1919.

77 MNL BaML VI. 502. Bvm. és Pécs v. Tanfelügyelőségének iratai, 62/1921.

${ }^{78}$ MNL BaML VI. 502. Bvm. és Pécs v. Tanfelügyelőségének iratai, 44/1920.

${ }^{79}$ MNL BaML VI. 502. Bvm. és Pécs v. Tanfelügyelőségének iratai, 356/1920.

${ }^{80}$ MNL BaML VI. 502. Bvm. és Pécs v. Tanfelügyelőségének iratai, 46/1919.
} 
volt, községe is igyekezett közbenjárni érdekében, ugyanakkor a miniszter felhívta rá a tanfelügyelő figyelmét, hogy a pécsváradi járási munkástanács elnöke is volt, ennek megfelelően kivizsgálása indokolt. Haller kiokította a tanfelügyelőt arról is, hogy „Tanfelügyelő úrnak bünügyi nyomozás során ốrizet alá vont tanitók szabadlábra belyezése iránt elöterjesztést tenni nemcsak nem tartozik feladatai közé, hanem az. állami tanfelügyelónek nevelési és oktatási érdekböl épen az, ellenkęő álláspontot kell képviselnie, aza a mindaddig, mig egy ilyen tanitónak teljes megbiðhatósága kétséget kizáróan igazolva nincs, magasabb állami és erkölcsi érdekekeböl a nevelés és oktatás munkáját kezébe adnia nem szabad”. A korszak nemzeti és valláserkölcsös neveléspolitikája megjelent a miniszter azirányú elvárásában is, amellyel felszólította a tanfelügyelőt, hogy ,jelen nebéz idöben, mikor az iskolában vissza kell állitani a hazafias és valláserkölcsös nevelést és oktatást és mikor a tanitóságot a kommunizmusban terheltektöl meg kell tisztitani: Tanfelügyelö úr is a rend megteremtése körül a legerélyesebb kézzel múködik közre s a kitúpött céltól semmiféle személyes vagy melléktekintetekkel magát eltérittetni nem engedi. Sajnálnám, ha épen most, mikor oly fontos erköllsi és állami érdekeke védelméról van sæó, Tanfelügyelö úr nem bizonyulna oly helytállónak, mint elózó állomásán”. A tanfelügyelőt végül azonnali intézkedésre hívta fel az iskola működésének helyreállitása iránt. ${ }^{81}$ Ezzel szemben például Csillag helyére már megtörtént a helyettes tanító, Scherlaub Mibály kinevezése, aki 1920 áprilisában meg is kezdte múködését. ${ }^{82}$ Klier és Szekeres 1920. augusztus 22-i jelentés szerint állásukban múködtek tovább, Gocsál nevéhez ekkor az iskolaszéki elnök azt a megjegyzést füzte, hogy ,jelenleg nem müködik, mivel kommunista magaviselete miatt fogságra itéltetett”, helyette Berényi Lajos államilag kirendelt tanító végzete az oktatást. ${ }^{83}$

Albert tevékenysége a többi tanítótól eltérően nem a levéltári iratokból tárul fel előttünk, tekintettel arra, hogy a fenti megemlítésen felül nem maradt nyoma ügyének a tanfelügyelőségi iratokban. Azonban egykori tanítványa visszaemlékezései alapján némi információt megtudhatunk arról a tanítóról is, aki nem kisebb szerepet vállalt a Tanácsköztársaság idején, mint a helyi tanítók szakszervezetének 1919. április 3-án megválasztott elnöki posztját. ${ }^{84}$ Tanítványa 50 évvel későbbi visszaemlékezéséből kiderül, hogy Albert Kisvaszaron három évtizedig múködött tanítóként. Ô szerkesztette a Tanácsköztársaság alatt a Sásd és Vidéke című lapot ${ }^{85}$, amely a helyi plébánia naplója szerint „még az imént szocialista irányu lap - most egyszerre vérvörössé vedlik át”. Az említett naplóból tűnik ki az is, hogy tevékenyen közremúködött a lakosság körében a kommunista eszmék terjesztésében: „népnevelóböl néprontó lett - vallás- és egyházellenes tárcákat ir az ujságjában”. Ezzel szemben tanítványa pozitívumként említette a fentieket, hozzátéve, hogy Albert május 1-i gyűlést és erdei ünnepséget szervezett. A proletárdiktatúra bukását követő eseményekről a tanítvány által közvetítve a következőképpen számolt be a plébánia naplója: „A kommün alatt vétkęőkeet összefogdossák, megverik, üldörik, elkergetik. Igy járt sok magáról megfeledkęett tanitó, köztük Albert István belybeli tanitó (...) is, akit a csendörök augus₹tus 18-án vittek Sásdra - és ott letartórtatták és ... viæsgálati fogságban tartották. (...) 1920.

\footnotetext{
${ }^{81}$ MNL BaML VI. 502. Bvm. és Pécs v. Tanfelügyelőségének iratai, 91/1920.

${ }^{82}$ MNL BaML VI. 502. Bvm. és Pécs v. Tanfelügyelőségének iratai, 251/1920.

${ }^{83}$ MNL BaML VI. 502. Bvm. és Pécs v. Tanfelügyelőségének iratai, 223/1920.

84 BODÓ, Adalékok a tanügyigazgatás és a pedagógusok szakszervezetének Baranya megyei történetéhez a Tanácsköztársaság idejéből 86.

85 A Sásd és Vidéke című lap Albert főszerkesztősége alatt a Tanácsköztársaság idején beszámolt a legfontosabb helyi eseményekről, mint például a közoktatásügyi népbiztos rendeleteiről és azok végrehajtásáról, a vármegyei művelődési osztály intéző bizottságának és a tanítók helyi szakszervezetének megalakulásáról; utóbbinak elnöke Albert, alelnöke Forrai, titkára Csillag lett és amely eseményt éppen a főszerkesztő méltatta a leglelkesebben. A lap azért is töltött be fontos szerepet ekkor, mert az Lengyel László Béla, a vármegye múvelődési megbízottjának 27/1919. sz. alatti, 1919. július 14-én megjelent rendelete szerint hivatalos lapnak volt tekintendő, tehát kötelező volt rá előfizetni, mivel ebben jelentek meg a tanítókat érintő rendelkezések. Bővebben lásd: BODÓ, Adalékok a tanügyigazgatás és a pedagógusok szakszervezetének Baranya megyei történetéhez a Tanácsköztársaság idejéből 83-103.
} 
március elején Albert István, kitöltvén félesztendei fogházbüntetését, Kaposvárról hazajön”. Tárgyalása 1922. május 20-án volt, amelyen állásvesztésre ítélték, ezt követően elhagyta a községet. ${ }^{86}$ Községi tanítóról lévén szó, egyházi fegyelmi eljárás feltételezhetően nem indult.

Hering mecsekjánosi római katolikus tanító fegyelmijének érdekes előzménye az általa a tanfelügyelőnek még a vizsgálat előtt, 1919. november 24-én írt panaszlevele. Levelét rögtön azzal kezdte, hogy „kommunista üzelmek gyanuja miatt a föszolgabírósághoz kihallgatásra voltam beidézve” és ekkor szerette volna felkeresni a tanfelügyelőt is, de mivel nem találta, levelet hagyott neki; hosszasan leírta panaszait az elmúlt 16 évrôl, mióta az állását betölti. Megemlítette, hogy az elôtte kényszernyugdíjazott tanító és a plébános valamint közötte folyamatosak a súrlódások, a volt tanító mindenbe „belekontárkodik”; az ellenszenv okait a tanító abban látta, hogy ő magát mélyen vallásosnak tartja, katona is volt és ezért rendes, precíz, a plébános pedig „végletekig rendetlen” valamint „vallásos meggyőódésében nem a legszilárdabban állo’. Mindezek következményeként beszámolt arról, hogy folyamatos feljelentések áldozata volt, amelyek megalapozatlannak bizonyultak, így ártani nem tudtak neki. Hosszan kifejtette az iskola háború alatti történetét is, illetve, hogy négy év után hadirokkantként hazatérve milyen állapotokkal kellett szembenéznie; hozzátette, hogy ugyan egy teljes tanévre szabadságolták, ő ezt az időt a tanításban keletkezett lemaradás („1914-ben a plébános vállalta magára a tanítást. Be is ment hetenkint egyszer, néba kétszer. 1915-ben egyáltalán nem volt tanitás. 1916-1917-ben alkalmaztak egy Lovas Imre nevü, magát kántortanitónak kiadó egyént, a ki a harangozáshoz talán konyitott, de a tanitáshoz analfabéta volt.") pótlására használta fel. Ennek ellenére a tanulók gyenge tudása miatt őt hibáztatták. „Köz̧ben kitört a kommunižmus és bála Istennek örökre meg is bukott. Elkeezdódött a hajsza a tanitók ellen. Ez régi ellenségeimnek kapóra jött. Most vagy soha! Minden, a Község és egyesek javára szolgáló, a kommunis fosztogatésoktól védô és megóvó cselekedeteimet, ellenem használták fel és kommunis üzelmekkel vádoltak meg. Természetesen egyetlen vádpont sem állja meg a belyét. Legnagyobb rész̨t tiszta koholmány, kisebb része pedig a valóság szándékos elferditése.” Az iskola ebben a tanévben múködését még nem kezdte meg, ugyanis a gondnok - a tanító állítása szerint - kizárta mind a tanítót, mind a plébánost, és bár onnan a gyermekeknek a tankönyveket kiosztotta, tagadta, hogy nála lenne az iskola kulcsa. Ez a fordulat csupán azért fontos, mert Hering felháborodva jegyezte meg azt is, hogy

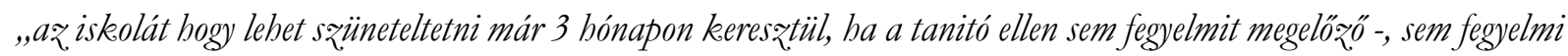
vizsgálat nincs?" ${ }^{87}$ Azonban, ha ekkor még nem is volt fegyelmije folyamatban, beigazolódott a tanító félelme, hiszen a fentebb idézett kimutatás szerint 1920 januárjában már eljárás alá vonták. Az, hogy végül az ügyből mi következett, a továbbiakban még kiderül, azonban annyit előrevetíthetünk, hogy az érintettek tájékoztatása mindenesetre kétségesnek mondható, tekintettel arra, hogy 1921 szeptemberében Hering a tanfelügyelőtől kért tájékoztatást: „....) Nagyságodtól értesültek arról, hogy fegyelmi ügyem végleg, javamra, elintéztetett. Mind hogy erröl hivatalos értesités hozzám még a mai napig sem érkezett el, (...) kérem sürgös intézlkedését.' ${ }^{88}$

Muttnyáns₹ky azon kevesek közé tartozik, akiket az egyházmegyei fegyelmi tanács felmentett a vádak alól. 1920. november 30-án kelt értesítés szerint az eljárás azzal zárult, hogy a tanítónőt felmentették, „mert az ellene fölhozott vádak nem lettek beigazolva”. Az eljárás ugyanígy alakult Walz Lipót baranyaszentgyörgyi római katolikus tanítóval szemben, az ő ügyének már csak e végső mozzanatai lelhetőek fel a tanfelügyelőségi iratokban, az eljárás megindításának körülményei nem derülnek ki. ${ }^{89}$

\footnotetext{
${ }^{86}$ MIKLÓS, Albert István a barananyai haladó tanítómozgalom élvonalában 103-108.

${ }^{87}$ MNL BaML VI. 502. Bvm. és Pécs v. Tanfelügyelőségének iratai, 114/1919.

${ }^{88}$ MNL BaML VI. 502. Bvm. és Pécs v. Tanfelügyelőségének iratai, 44/1921.

${ }^{89}$ MNL BaML VI. 502. Bvm. és Pécs v. Tanfelügyelőségének iratai, 652/1921.
} 
A vizsgálat következtében Albauer állásáról 1920. július 1-tôl lemondott. ${ }^{90}$ Példáját valószínúleg többen követték, a tanfelügyelőségi iratok között erre utal a „Kommunista magatartásuk miatt lemondott tanitók nyilvántartása" tárgyú fejléc, amely alatt azonban magát a nyilvántartást nem találjuk. ${ }^{11}$ Szintén ezt erôsíti meg a vallás- és közoktatásügyi miniszter nevében Dr. Szǘcs István miniszteri tanácsos részéről majd egy évvel korábban, 1919. december 2-án kelt levél, amely arról értesíti a tanfelügyelőt, hogy „A bolsevizmus üzelmeiben részt vett tanitók nagy része az, igazságszolgáltatás elöl úgy igyekęnek kitérni, hogy állásáról lemond, avagy azt egyszerüen elhagyja s más tankerületben próbál új álláshor jutni”. A felelősségre vonás ilyen módon való elkerülésének megakadályozása érdekében elrendelte a lemondott, lemondatott vagy állásukat egyéb módon elhagyott tanítók adatait tartalmazó nyilvántartás elkészítését az utolsó állomáshely megjelölésével, valamint az 1919. augusztus 1-et követően a tankerület területén szolgálatba lépett tanítóktól a Tanácsköztársaság idején tanúsított magatartásukról igazolvány kérését. A miniszteri tanácsos végül arról is tájékoztatta, hogy az egyházi föhatóságokat szintén megkereste ugyanebben az ügyben. ${ }^{92} \mathrm{~A}$ felelősségre vonás lemondás útján való elkerülése igen hatékony útnak bizonyult a tanítók számára, hiszen többekkel szemben ebből az okból szüntette be később az eljárást az egyházi hatóság.

A püspöki provicarius 1921. január 4-én a tanfelügyelő korábbi megkeresésére válaszolva ismertette a fegyelmi eljárás alá vont tanítók ügyeinek állását: Pokorny, Szeleeres, Neubauer, Klier, Csonka, $W$ alz ügye a fegyelmi tanács felmentésével zárult; Muttnyáns zkyval szemben az eljárást - fent ismertetett okokból - a fegyelmi tanács beszüntette; Albauer és Forrai lemondását az egyházi főhatóság elfogadta, ez alapján az eljárást velük szemben a fegyelmi tanács beszüntette; Gyurkovicsot a fegyelmi tanács pénzbírságra, magasabb fizetési osztályba való előlépésének 2 évre szóló megvonására és az eljárási költségek fedezésére ítélte; Hambergerre magasabb fizetési osztályba való előlépésének 1 évre szóló megvonását és az eljárási költségek fedezését szabták ki; Halmai dorgálást kapott, valamint magasabb fizetési osztályba való előlépésének 2 évre szóló megvonására és az eljárási költségek fedezésére ítélték; Hubert és Heringet a fegyelmi tanács szintén dorgálásra ítélte és a költségek fedezésére kötelezte; Csillag ügye a tanító „letartóztatása miatt nagy késedelmet szenvedett, s csak eqután jutott abba a stádiumbam hogy ügyész inditvány adassék ki”; Gocsál esetében az ügyészi indítvány készül.93

Láthatjuk, hogy az ekkor már két éve tartó eljárásoknak még közel sem értek teljes mértékben a végére az egyházi hatóságok sem, illetve ekkor még adott esetben hátra volt a világi hatóság eljárása, tekintettel arra, hogy a miniszter 1921. március 16-án felkereste a tanfelügyelőt, és külön levelekben közölte több tanító tekintetében, hogy az egyházmegye fegyelmi tanácsa ítéletet hozott, amelyet azzal küldött meg a tanfelügyelőnek, hogy nyilatkozzon róla: az egyházi hatóság ítéletének tudomásul vételét vagy a fegyelmi ügynek a közigazgatási bizottsághoz való áttételét tartja indokoltnak. Ez azért volt fontos, mert - ahogy korábban ismertettük - a miniszter volt jogosult elrendelni az eljárást a közigazgatási bizottság előtt. Hering ügyében a fegyelmi tanács 1920. december 9-én hozta meg ítéletét, amelye a dokumentumok között nincsen csatolva, annak tartalmára a tanfelügyelő válaszából lehet következtetni: a fegyelmi már folyamatban van a közigazgatási bizottság előtt is, azonban felfüggesztették az egyház általi lefolytatásáig; utóbbi

\footnotetext{
${ }^{90}$ MNL BaML VI. 502. Bvm. és Pécs v. Tanfelügyelőségének iratai, 600/1920.

${ }^{91}$ MNL BaML VI. 502. Bvm. és Pécs v. Tanfelügyelőségének iratai, 932/1920.

${ }^{2}$ MNL BaML VI. 502. Bvm. és Pécs v. Tanfelügyelőségének iratai, szám nélkül (197426/919 szám VKM) A vallásés közoktatásügyi magyar minisztertől valamennyi vármegyei tanfelügyelő urnak és tanfelügyelőségi kirendeltségnek, 1919. december 2.

${ }^{93}$ MNL BaML VI. 502. Bvm. és Pécs v. Tanfelügyelőségének iratai, 46/1921.
} 
eljárást már be is fejezték és az egyházi hatóság Heringet vétkesnek mondta ki. ${ }^{94}$ Halmai esetében a minisztérium részéről ugyanekkor érkezett levélből a püspöki provicarius által írtakhoz képest annyi eltérés mutatkozik, hogy eszerint az egyházi fegyelmi tanács Halmait pénzbírságra ítélte dorgálás helyett a magasabb fizetési osztályba való előlépésének 2 évre való megvonása, valamint az eljárási költségek megfizetése mellett. ${ }^{95}$ A fenti tartalmú levél a minisztériumtól megérkezett Klierre ${ }^{96}$ és Muttnyánszkyra $^{97}$ vonatkozóan, majd május 2-án $S_{\text {zekeres }}{ }^{98}$ és Neubauer ${ }^{99}$ ügyében is. Ezekhez hozzátehetjük, hogy a felmentő határozatra tekintettel az egyház ítéletének a miniszter általi tudomásulvétele következett be, ügyük nem került a közigazgatási bizottság mint világi hatóság elé. Csillag $g^{100}$ és Forrai ${ }^{101}$ esetében ugyan már korábban, 1920. június 20-án megérkezett ez a bizonyos levél a közigazgatási bizottság elé utalás kérdésében, az ô ügyük - mivel a közigazgatási bizottság még az egyház intézkedése után maga is lefolytatta a vizsgálatot - hosszabban folytatódott. Forrai ellen elrendelt fegyelmi vizsgálat foganatosításának a hegyháti járás főszolgabírájához való áthelyezéséről szóló határozatában a közigazgatási bizottság leírta, hogy a tanító „alaposan gyanusitható azzal, bogy a kommunisztikus irányzat érdekében nemcsak az iskolában, banem társadalmi és irodalmi téren is nagy tevékenységet fejtett ki, megszervezte az iskolai munkástanácsot, kommunisztikus felolvasásokekal megmételyezte az iskolásgyermekeke lelkét s a gyónás ellen nyilatkozott”. 102 Csillag fegyelmi eljárásának lefolytatására a közigazgatási bizottság ugyanígy a hegyháti járás főszolgabíráját kérte fel határozatában; ennek során ismertette az eljárás alapjául szolgáló indokokat a következők szerint: „exponált kommunista volt, általa egyháabéri burssiknak nevezett községi lakosokat agyonlövéssel fenyegette, ha a bolsevik uralom ellen csak panaszkodni is mertek, a 'Dicsértessék. Kun Béla, a világ megváltója' köszönést reá eröszakolta az iskolásgyermekekere”. Miután a főszolgabíró megtette jelentését a közigazgatási bizottsághoz, az kitűzte Csillag nyilvános tárgyalását 1922. május 22-ére. ${ }^{103}$

Az események ezen a ponton félbeszakadnak, majd az 1930-as években ismét előveszik néhány tanító ügyét. Így történt 1932-ben Csillag, Forrai, Albauer, Gyurkovics, 1933-ban Gocsál és Hamberger esetében. 1932. április 29-én a hegyháti járás főszolgabírája felkereste a tanfelügyelőséget, hogy közölje vele, indult-e, illetve pontosan milyen cselekmény miatt indult eljárás, majd milyen eredménnyel végződött Csillag, Forrai, Albauer és Gyurkovics tanítókkal szemben. A tanfelügyelő erre adott válaszából megtudhatjuk az eljárások kimenetelét. Csillagot a közigazgatási bizottság állásától való elmozdításra ítélte azzal, hogy 3 évig sehol nem alkalmazható; tekintettel arra, hogy ez az időtartam közben eltelt, a tanfelügyelő már vázsnoki tanítóként hivatkozik Csillagra. Forrait a közigazgatási bizottság szintén elmozdította állásából, egyéb korlátozások nélkül. Albauer - ekkor már szintén máshol, Ibafán, községi iskolánál alkalmazott tanító - ügyében beszámol arról, hogy vele szemben a pécsi püspök az eljárást beszüntette, mert állásáról lemondott, amelyet a vallás- és közoktatásügyi miniszter tudomásul vett; emellett azonban a Kaposvári Kir. Törvényszék ítéletében a tanítóra izgatás és személyes szabadság megsértése miatt 5 havi fogházat szabott ki. Gyurkovicsot állásából elmozdították. ${ }^{104}$

\footnotetext{
94 MNL BaML VI. 502. Bvm. és Pécs v. Tanfelügyelőségének iratai, 358/1921.

${ }^{95}$ MNL BaML VI. 502. Bvm. és Pécs v. Tanfelügyelőségének iratai, 716/1921.

${ }^{96}$ MNL BaML VI. 502. Bvm. és Pécs v. Tanfelügyelőségének iratai, 724/1921.

${ }^{97}$ MNL BaML VI. 502. Bvm. és Pécs v. Tanfelügyelőségének iratai, 709/1921.

${ }^{98}$ MNL BaML VI. 502. Bvm. és Pécs v. Tanfelügyelőségének iratai, 772/1921, 515/1921.

${ }^{99}$ MNL BaML VI. 502. Bvm. és Pécs v. Tanfelügyelőségének iratai, 773/1920, 516/1921.

${ }^{100}$ MNL BaML VI. 502. Bvm. és Pécs v. Tanfelügyelőségének iratai, 555/1920.

${ }^{101}$ MNL BaML VI. 502. Bvm. és Pécs v. Tanfelügyelőségének iratai, 554/1920.

102 MNL BaML VI. 502. Bvm. és Pécs v. Tanfelügyelőségének iratai, 425/1921.

103 MNL BaML VI. 502. Bvm. és Pécs v. Tanfelügyelőségének iratai, 498/1921.

${ }^{104}$ MNL BaML VI. 502. Bvm. és Pécs v. Tanfelügyelőségének iratai, 1010/1932.
} 
Gocsál (akinek neve ekkor már más írásmóddal, „Gotsál”-ként szerepel) ügyében 1933. február 9-én szintén a hegyháti járás főszolgabírája felkeresése kapcsán merült fel az egy évtizeddel korábbi fegyelmi eljárás. Az ide csatolt iratokból széleskörű képet kaphatunk a tanító elleni eljárás eredményeiről, melyről eddig csupán annyit tudtunk, hogy „az ügyészi inditvány késæüll”. A Vallás- és Közoktatásügyi Minisztériumból a pécsi püspöknek címzett, és a tanfelügyelőnek másolatban küldött levélből kiderül, hogy Gocsált az egyházi fegyelmi tanács állásából elmozdította, az egyházmegye területén nyilvános tanítói működéstől eltiltotta (ehhez hasonlóan súlyos büntetéssel nemigen találkozhattunk más tanítók esetében), valamint az eljárási költségek megfizetésére kötelezte, amelyet a miniszter tudomásul vett és ennek megfelelően intézkedett a tanító államsegélyének beszüntetéséről és az országos tanítói nyugdíjintézeti tagok közül való törléséről. Amikor a tanfelügyelő az ügyről szóló jelentését felküldte a minisztériumba, hozzátette azt is, hogy a Kaposvári Kir. Törvényszék a tanítót izgatás bűntette és vallás elleni vétség miatt 1 évi börtönbüntetésre ítélte, ezért nem tartja elegendőnek, hogy csak a pécsi egyházmegye területén legyen eltiltva a tanítói tevékenységtől. ${ }^{105}$ Látható, hogy Gocsál esetében mind az egyházi, mind a világi hatóság meglehetôsen súlyos büntetést szabott ki.

1933. június 20-án Hamberger, illetve mellette két gödreszentmártoni tanítónő, Lehockzyy Katalin és Pozsonyi Margit „kommunismus alatti magatartás miatt indult” fegyelmi eljárása felől érdeklődött a hegyháti járás főszolgabírája a tanfelügyelőnél. Utóbbi két tanítónő esetével a '20-as évekbeli iratokban nem találkozhatunk, mivel Pozsonyi iratai mind át lettek csatolva az 1933-as évhez, Lehocky ügye pedig itt sem található. Tekintettel arra, hogy a korábbiak során tárgyalt Muttnyáns₹ky kivételével tanítónő ellen elrendelt fegyelmi vizsgálat nem lelhető fel a tanfelügyelőségi iratokban, továbbá állami tanítónőről van szó a korábbi, többségében felekezeti tanítókkal szemben, érdekes e helyütt röviden áttekinteni Pozsonyi ügyét. A tanítónőt a közigazgatási bizottság saját költségén más állomásra való áthelyezésre ítélte, aki ez ellen a fellebbezett a minisztériumhoz, ami az ítéletet helybenhagyta. A közigazgatási bizottság ítéletének indokolása szerint az eljárás alapjául az szolgált, hogy Pozsonyi „Gödreszentmártonban a proletár diktatura idején lelkes kommunistának vallotta magát, a lakósság és különösen a gazdasági cselédek között agitált és az ugynevezett tanácskormány közegeivel összeköttetést tartott fenn”. Ezt követte azoknak a felsorolása, amelyek a vádpontok közül bizonyítottak voltak tanúvallomások által: „,...) a község ügyeibe beleszólást követelt és a községi ülések lefolyását ellenörizni akarta. (...) a sásdi tanitógyülésen a kereszt levétel kérdésében élénken exponálta magát a keresz̨ levétele mellett. (...) a kommunizฺmusról dicséröleg nyilatkozott és attól a tanitók helyzetének javulását remélte. A tanitónó beismerésével és több tanu vallomásával megállapitást nyert, hogy a tanitónö egy Vince nevü politikai nyomozóval többšör érintkezett. (...) átképzó tanfolyamon részt vett”. A közigazgatási bizottság előtt nyilvános tárgyalása 1922. április 11-én, március 30-án és június 22-én volt. A közigazgatási bizottság ítéletét megelőzően a fent említett esetekhez hasonlóan eljárt a hegyháti járás fôszolgabírája. Végül Hamberger fegyelmije is ismét felszínre került. Esetében a világi hatóságok előtti eljárása során a Kaposvári Kir. Törvényszék felmentő itéletet hozott izgatás és vallás elleni bűncselekmény tárgyában. Bár az indokolásban leírnak olyan tanúvallomásokat, amelyek alapján Hamberger magatartása kifogásolható - az iskolából eltávolított keresztet a helyiek a tanítónál keresték, aki erre azt felelte: „a templom padlásán a lom köoött van valami fene”-, a Törvényszék úgy értékelte ezeket, hogy bűncselekményt nem valósított meg velük, mivel kijelentését nem vallásos szertartás alkalmával tette. ${ }^{106}$

${ }^{105}$ MNL BaML VI. 502. Bvm. és Pécs v. Tanfelügyelőségének iratai, 10/1933.

${ }^{106}$ MNL BaML VI. 502. Bvm. és Pécs v. Tanfelügyelőségének iratai, 1611/1933. 
A fenti események részletezését követően érdemes - továbbra is kellő távolságtartással kezelve a tényeket, csupán érdekességképpen felvillantva a következőket - egy másik megközelítésből szemügyre venni a történteket. Azt, hogy a tanítók tetteinek megítélése csupán nézőpont kérdése, mi sem bizonyítja jobban - miután láttuk a Horthy-korszakban történt felelősségre vonásokat, néhány évtizedet előre ugorva az időben -, mint Ballér Endre 1969-ben írt szavai: „A tanfelügyelöségi iratok (...) sok pedagógus kálváriáját tartalmazzák. Az üldözések hevében a fellélegző papi s uri reakció arra is gondolt, hogy számba vegye, mit „vétettek” ezek a pedagógusok 1919-ben, a Tanácsköztársaság idején. Eqeek az anyagok igen becsesek számunkra, mert egyik bizonyitékunk arra, bogy milyen sok megyei pedagógus vált az elsö magyar proletárforradalom idején - nyugodtan mondhatjuk - a szocialista tanok bivévé, kommunistává”. Az idézett sorok írója ezt követően dicsőítve - bár hozzátéve, hogy a rendszer bukását követően nem mind ,az̧onosultak már forradalmi multjukeal’ - sorolja fel a számunkra már ismerősen csengő neveket mint a magyarországi kommunizmus úttörőit és áldozatos híveit: Albert István, Csillag Jenó, Forrai István, Pokorny Márton, Szekeres József, Csonka Andor, Gyurkovics Sándor, Gocsál József, Hamberger Ferenc, Huber János, Neubauer Gyula, Pozsonyi Margit. ${ }^{107}$

\section{6. Összegzés}

A Tanácsköztársaság alapjait tekintve szervezte át az iskolaügyet. Az egyházak befolyását igyekeztek csökkenteni, ez az iskola területén oly módon jelent meg, hogy ideológiai alapon vallássemlegesség megvalósítására törekedtek. Ennek érdekében az iskolákat - fontos hozzátenni, hogy nem csak a felekezetek által fenntartott intézményeket, hanem ugyanúgy a községi, a társulati és a magán fenntartású iskolákat is - államosították, a nevelés terén elsődleges szerepet az államnak szántak. A Forradalmi Kormányzótanács és a Vallás- és Közoktatásügyi Minisztériumot ekkor felváltó Közoktatásügyi Népbiztosság számos intézkedést tett az iskolák állami átvétele, a vallás kiszorítása iránt. A tanítókat igyekeztek kommunista szellemben átnevelni, a papokat, apácákat és szerzeteseket tanítóként akkor alkalmazták tovább, ha ôk világi személyeknek nyilvánították magukat. Az államosítás mellett az oktatási rendszer problémáit radikális ütemú megoldásokkal, azonnal szerették volna megoldani: bevezették az osztott oktatást, a nyolcosztályos oktatást, a zsúfoltság megszüntetése érdekében új iskolák építését helyezték kilátásba valamint emelték a tanerők létszámát. Ez több esetben elnyerhette a tanítók támogatását, akiknek nagy többsége - a különböző fórumaikon előadottak szerint - alapvetôen elégedetlen volt korábbi (anyagi és társadalmi) helyzetével.

A rendszer bukását követően éles politikai váltás következett be, a hangsúly a vallásos nevelésen még élénkebben jelentkezett, mint azt megelőzően. Ennek megfelelően a Tanácsköztársaság intézkedéseit támogató, vagy legalábbis azt kiszolgáló tanítók kivizsgálása elengedhetetlennek bizonyult. A fegyelmi eljárások által feltárt iratok alapján az egyik levonható következtetés, hogy a tanítók, akiknek feladata a gyermekek vallásos-erkölcsös nevelése volt, hajlamosak voltak ezt félretéve is határozottan hangot adni politikai irányultságuknak. Ugyanakkor, ahogyan az több esetből is kiderül, ezek a felelősségre vonások személyes bosszú eszközeként is szolgálhattak, amikor a legtöbb tanítót kivizsgálták, és sok esetben hamis vádakkal vagy megalapozatlanul tettek ellenük feljelentést, ahogy erről Hering római katolikus felekezeti tanító is beszámolt a tanfelügyelőhöz intézett panaszlevelében.

107 BALLÉR, Haladó pedagógiai eszmék, törekvések Baranyában a XX. század elejétől a Tanácsköztársaság megdöntéséig 79-80. 


\section{Felhasznált források és irodalom}

1868. évi XXXVIII. törvénycikk a népiskolai közoktatás tárgyában

1893. évi XXVI. törvénycikk a községi, valamint a hitfelekezetek által fentartott elemi iskolákban működő tanitók és tanitónők fizetésének rendezéséről

1907. évi XXVI. törvénycikk az állami elemi népiskolai tanitók illetményeinek szabályozásáról és az állami népiskolák helyi felügyeletéről

1907. évi XXVII. törvénycikk a nem állami elemi népiskolák jogviszonyairól és a községi és hitfelekezeti néptanitók járandóságairól

1913. évi XV. törvénycikk az állami elemi népiskolai tanitók illetményeinek rendezéséről

1913. évi XVI. törvénycikk a községi és hitfelekezeti elemi népiskolai tanitók illetményeinek rendezéséről

1918. évi VIII. néptörvény az elemi népiskolai tanítóknak és tanítónőknek, a kisebb képesítésű gazdasági szaktanítóknak (szaktanítónőknek), továbbá az óvónőknek az állami tisztviselői fizetési osztályokba való sorolása, valamint illetmény- és nyugdijjügyi viszonyainak rendezéséről

1919. évi V. néptörvény a vallásügyi s közoktatásügyi igazgatásról

A Magyarországi Szocialista Szövetséges Tanácsköztársaság alkotmánya

A magyar közoktatásügyi miniszter 1919. évi 1.746. ein. számú rendelete, a vallásoktatással kapcsolatos teendők alól való mentesítésről https://library.hungaricana.hu/hu/view/OGYK_RT_1919/?pg=695\&layout=s (2020. 07. 13.)

A vallás- és közoktatásügyi miniszter 1919. évi 4.507 eln. számú rendelete a nevelési és oktatási intézetek köztulajdonba vétele és a művelődés és oktatás ügyei igazgatásának szabályozása tárgyában a volt tanácskormány által kiadott rendelkezések hatályon kívül helyezéséről https://library.hungaricana.hu/hu/view/OGYK_RT_1919/?pg=1816\&layout=s (2020.07.13.)

Az új iskola. Világ, X. évf. 86. szám, 1919. április 11. 7.

BALLÉR Endre: Haladó pedagógiai eszmék, törekvések Baranyában a XX. század elejétől a Tanácsköztársaság megdöntéséig. In: SIMON Gyula (szerk.): Tanulmányok a Magyar Tanácsköztársaság nevelésügyének történetéből. Budapest 1969, 66-82.

BENCZE Imre - LADÁNYI Sándor: A polgári demokratikus forradalom és az egyházak. In: BALOGH Margit - BEKÉNY István - DÁNYI Dezső - ÉLESZTŐs László - HERNÁDI László Mihály - OROS Iván - TINER Tibor (szerk.): Magyarország a XX. században. II. kötet, Szekszárd 1997, 327-331.

BENCZE Imre - LADÁNYI Sándor: A Tanácsköztársaság és az egyházak. In: BALOGH Margit - BEKÉNY István - DÁNYI Dezső - ÉLESZTŐs László - HERNÁDI László Mihály - OROS Iván - TINER Tibor (szerk.): Magyarország a XX. században. II. kötet, Szekszárd 1997, 331-336.

BODÓ László: Adalékok a tanügyigazgatás és a pedagógusok szakszervezetének Baranya megyei történetéhez a Tanácsköztársaság idejéből. In: SIMON Gyula (szerk.): Tanulmányok a Magyar Tanácsköztársaság nevelésügyének történetéből. Budapest 1969, 83-103.

BÖLÖNY József: Magyarország kormányai 1848-1975. Budapest 1978

Herger Csabáné: Auf dem Weg zur Autokratie? Kirchenpolitik in der Horthy-Ära in Ungarn. Krakowskie Studia z Historii Panstwa i Prawa. 2017/1 sz. 69-95.

KOMLÓsI Sándor: A Tanácsköztársaság közoktatásügyének néhány kérdése, különös tekintettel a Dunántúli iskolákra. In: SIMON Gyula (szerk.): Tanulmányok a Magyar Tanácsköztársaság nevelésügyének történetéből. Budapest 1969, 28-65.

KÖTE Sándor - RAVASZ János: Dokumentumok a magyar nevelés történetéből 1849-1919. Budapest 1979

Magyar Nemzeti Levéltár Baranya Megyei Levéltára (MNL BaML) VI. 502. Baranya vármegye és Pécs város Tanfelügyelőségének iratai: 114/1919, 17/1919, 175/1912, 22/1919, 22/1919, 223/1920, 251/1920, 3/1919, 348/1919, 356/1920, 44/1920, 44/1921, 652/1921, 600/1920, 932/1920, szám nélkül (197426/919 szám VKM), 46/1921, 358/1921, 716/1921, 724/1921, 709/1921, 772/1921, 515/1921, 773/1920, 516/1921, 555/1920, 554/1920, 425/1921, 498/1921, 1010/1932, 10/1933, 1611/1933, 114/1919, 46/1919, 5/1919, 6/1919, 60/1919, 62/1921, 63/1919, 56/1919, 91/1919, 57/1919, 74/1919, 134/1919, 91/1920, szám nélküli meghívó a „Baranyamegyei Tanítótestület” ülésére, szám nélküli felhívás a magyar tanítósághoz, szám nélkül (984/1919 püsp prov.), szám nélkül (ad. 511/1919 alisp.), szám nélkül (984/1919 püsp.prov.), szám nélkül (ad 1135-1140, 1153, 1154/1919 püsp.prov.), 110/1919

MANN Miklós: Magyar oktatáspolitikusok 1848-1998. Budapest 2001 
MANN Miklós: Oktatáspolitikusok és koncepciók a két világháború között. Budapest 1997

MIKLÓS Péter: Albert István a barananyai haladó tanítómozgalom élvonalában. In: SIMON Gyula (szerk.): Tanulmányok a Magyar Tanácsköztársaság nevelésügyének történetéből. Budapest 1969, 104-117.

NikLAi Patrícia Dominika: A nyolcosztályos népiskolai oktatás bevezetésének hatása az iskolalátogatással kapcsolatos szülői felügyeleti jogra. Díké 2019/1. sz. 101-110.

NikLAi Patrícia Dominika: Die Modernisierung des Volksunterrichts in Ungarn - Umsetzung des Gesetzes über den Volksunterricht im Komitat Baranya nach 1868. In: Journal on European History of Law 2018. Vol. 9/2018 No. 2., 231-235.

RAVASz János - FELKAI László - BELLÉr Béla - SiMON Gyula: A magyar nevelés története a feudalizmus és a kapitalizmus korában. Budapest 1960

SCHWEITZER Gábor: A magyar királyi köztársaságtól a magyar köztársaságig. Pécs 2017

SIMON Gyula: A Magyar Tanácsköztársaság nevelésügye. In: SIMON Gyula (szerk.): Tanulmányok a Magyar Tanácsköztársaság nevelésügyének történetéből. Budapest 1969, 7-27.

UJVÁRY Gábor: A Magyarországi Tanácsköztársaság kulturális politikája. https://honismeret.hu/honismeret-folyoirat/a-magyarorszagi-tanacskoztarsasag-kulturalis-politikaja (2020. 07. 13.) 